\title{
晹窒扶斯澘堂沸免疫元微粒子, 研究
}

\author{
にんひごりん反應キ呈スル物質八 \\ 補體結合抗原性キ有スルヤ
}

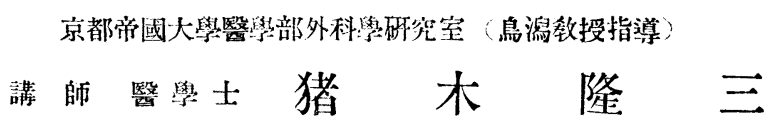

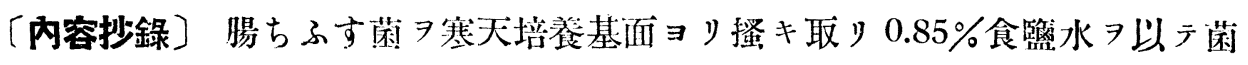

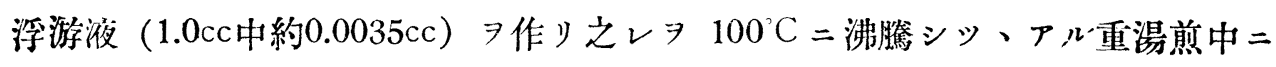
テ30分間加熱殺菌シ，然ル後遠心シソ八上澄液 $ヨ \mathrm{I}_{3}$ 陶土濾過壁二テ無菌的二濾 過シ腸ち子す菌㟟沸免疫元 (原液) 7 得.

カ、ル液ハにんハひぞりん反應中等度（强）陽性ナ!、更ニ之レヨ甲及ビて 二二分シ，甲八其儘（原液）トシ，乙ハ24時間 习限度トシテ 5 分間乾燥ころじ ゆーさ霊二テ透析シ而シテ透析內液及ビ透析外液习得タリ。

此八液ハ兩者共にんひどりん反應陽性:シテいあだねつと氏比色計 $=$ テ 100 分比 求ムレバ原夜 : 透析內液 : 透析外液 $=100: 52.3: 47.7$ ヨ示シタリ.

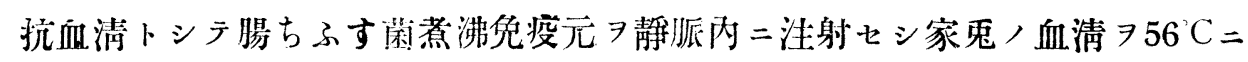
テ30分間加温セルモ, 7 取リタリ。

即于腸ち子方菌惹沸免疫元 (原液) 同透析內液及ビ透析外液，有スルにんひ

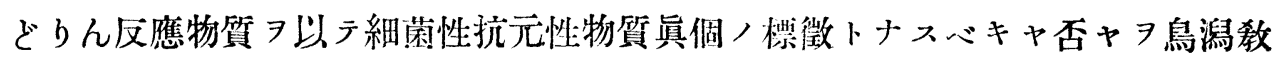
授，剧始セラレタル（容量的補體結合反應）特=ERR 第 1 及ビ第 2 結合型 準據シ以テソ, 意義如何习呤味セリ。

$\mathrm{E} \mathrm{RR}$ 二於ケル第 1 型結合二テハ原液及ビ透析内液

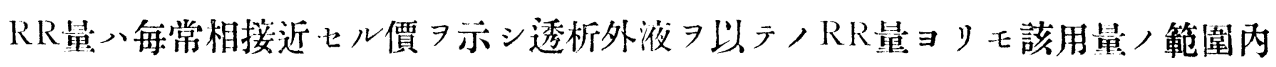
二於テハ常二比較ニナラザル程大ナリキ，而シテ透析外液（純にんひぼりん反 應性物質）二於テハ，ERR R結合關係、全ク立證セラレズシラ除性トナレリ。

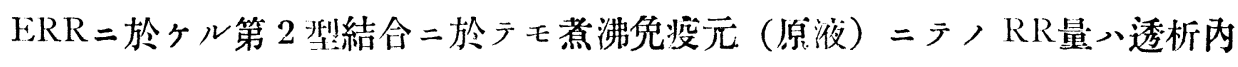
液ニテノ其レト略々相接シ僅少，差テホシタリ．換言スレバ兩抗原，抗原性能 働力二格段, 差习認メザリシモノナリ。透析外液ニアリテハ陽性, 補體結合反 
應ハ浱跡ダモ立證スルコトラ得ザリキ.

以上ノ所見、腸ちふす菌者沸免疫元ノにんひどりん反應性物質卜凝集反應， 所見換言スレバ家鬼, 全身性後天性自働免疫獲得，實際結果トモ全ク一致スル モノニシテ單二透析物質三純にんひどりん反應性物質ノミョ以テハ最早細菌性 抗原性物質ノ標徵トハナシ得ザルモノナリトノ結論二到達シタリ。

\section{目次}

第 1 章 緒言=實驗 $>$ 目的

第 2 章 實驗材料

第 3 章 檢查方法

第 4 章 容量的禣體結合反滤檢查方法/精密度 八吟味.

甲. 抗體前二著沸免疫元原液透析內㳸及ビ 透析外液, 單獨( SRR) 補體結合反應

乙，堂沸免疫元原液透析內液及七゙透析外液 /3抗原二テノ第1型抗體抗原 (ERR) 二依儿補體結合反隹

丙, 所見總括及ビ考察

第 5 章 容量的補體結合反應檢查方法/精密度 八吟味.
甲. 單獨補體結合反應 (SRR)

乙, 抗體抗原結合ニョル第 2 型補體結合反 礁 (ERR)

丙, 所見概括及七゙考察

第 6 章 3 抗原 / 單獨補體結合前二, 第 3 型抗 體抗原結合二依ル補體結合反仵二對入 ル影響

所見及ビ考察

第 7 章 所見總括及ビ考察

第 8 章 結 論

主要交献

路文自抄

\section{第 1 章 緒言一實駼ノ目的}

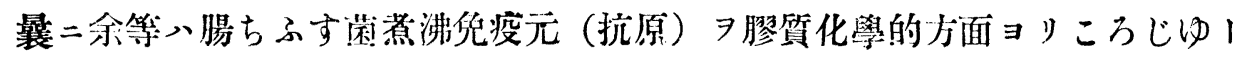

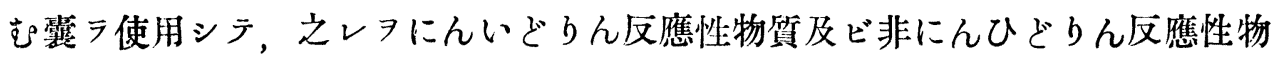
質ノ二因子二分析シ，此八ニッノ材料

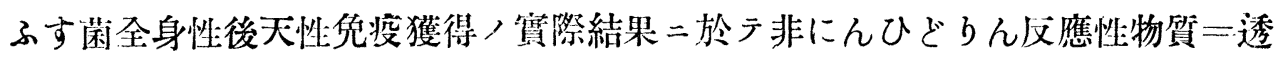

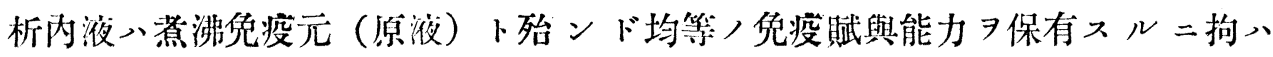
ズ，純にんひぎりん反應性物質(菌蛋白分解產物)ニアリテ入先痁賦與能力，換 言スレバ抗原性能働力全然缺如スル事习立證報告セ》。

余等今次更二進ミテ腸ちふす菌募沸免坄元透析内液及ビ透析外液=にんひぞ り 亿反應物質, 抗原性能働力 7 恩師鳥潟教授ノ创案セラレタル容量的補體結合 反應檢查法 ヨ應用シテ, 試驗管內二於テモ亦立證シ得ルャ否ヤ, 又試驗管內二 於ケル成績卜動物筫驗ノ所見卜ガ果シテー致スルモノナリヤ, 毁子動物體内二 
㺘木隆 $\quad$ 沋

(1901)

於テ先疫元性能働力無キ事卜試驗管內二於ヶル抗原性能働力無キコトハ兩々果 シテ原則的ニ一致スルモノナリャ否ヤ タ實驗結果二匡サント欲ス，是レ本研究 八目的ナリ.

\section{第 2 章䔬 驗 材料}

（1）腸ちふす笉煮沸免疫元（原液）.

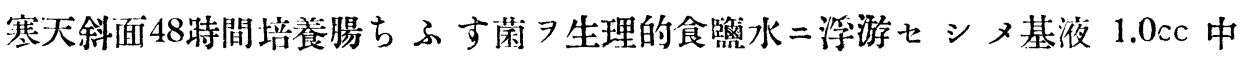
$=$ 約 $0.0035 \mathrm{cc}$ ノ菌體 $\ni$ 含有七シヌ，更 $=0.5 \%$ ，割合二石炭酸 加一，約 30 分 間手 ヨ以テ震湯シタル後 $100^{\circ} \mathrm{C}=$ テ30分間加熱シ, 自然二冷却ンル 待チテ, 6000 廻轉30分間遠心シ, ソノ上澄液 $7 \mathrm{~L}_{3}$ 腎過器 7 以テ無菌的二滤過七ルモノ二 シテにんひどりん反應中等度（强）陽性ナリ.

(2)ころじ।さ囊透析内液

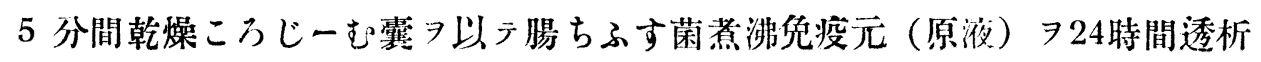
セル後ニ於ヶルころじーむ霍内液ナリ。

（3）ころじーむ囊透析外液一純にんひどりん反應性物質，5 分間乾燥ころじ

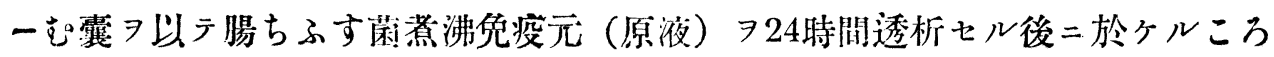
じーさ囊外液ニシテにんひどりん反應陽性ナリ。い・おどねつと氏比绝計二テ 測定シテ 100 分比 7 求ムレバ原液: 透析內液: 透析外液—100.0:52.3:47.7 7 示セリ.

（4）抗腸ちふす菌家鬼血清

腸ちふす菌募沸免疫元（䒩最基液 $1.0 \mathrm{cc}$ 中約 $0.0035 \mathrm{cc}$ ）， $1.5 \mathrm{cc} 75 \mathrm{H}$; 期 䦭内二家鬼，耳静脈內二注射シ，最後，注射日ヨリ1週間目二頸動脈ヨリ全探 血:シテ得タル血清 $756^{\circ} \mathrm{C} 30$ 分間加温シ，更二 $0.3 \%$ ノ割合二め己く製石炭阭 ヨ汃ヘタルモノナリ。本血清ノ凝集價、1:8000ナリキ.

(5) 血 球浮游 液

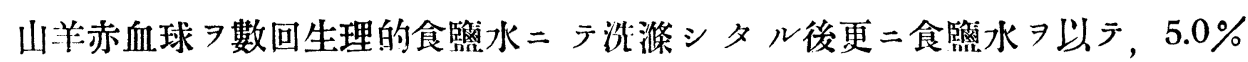
ノ割ニ稀釋シタルモノナリ。

（6）血球溶解性抗血清（へもりぢん）

山羊血球习家鬼,耳静脈內一泩射シテ得タル抗山羊血球家鬼血清 $556^{\circ} \mathrm{C}$ ノ 
水漕中ニテ30分間加温シテ，非働性トナシタルモノナリ.

(7) 補

體,

健康海猽，新鮮ナル血清 7 生理的食臨水ニテ10倍二稀釋シ使用セリ。

\section{第 3 章 檢 查 方 法}

（イ） 1 列ノ沈澱計二腸ちふす菌㞀沸免疫元原液, 同透析内液及ビ透析外液

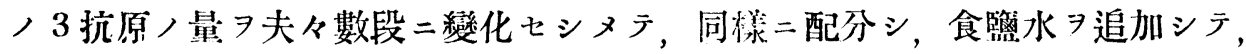
各同一量トナシタルモノ（單獨補體結合反應）或八更二前記ノモノ二抗體ノ夫 々同一量 ヨ配分シタルモ（第 1 悡抗體抗原補體結合反應, 塲合）八何レモ豫

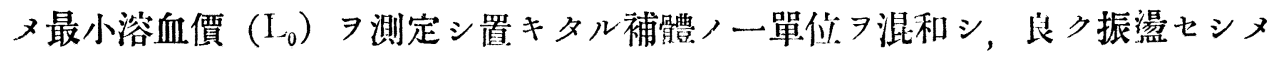

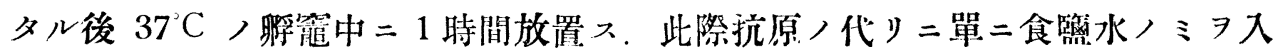
レタルモノタ作リテ對照トナセリ。

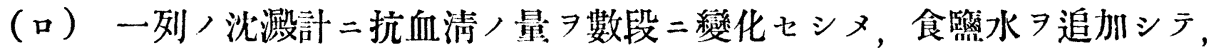

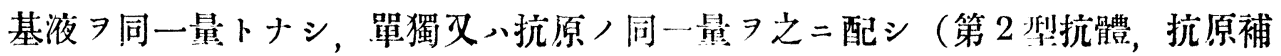

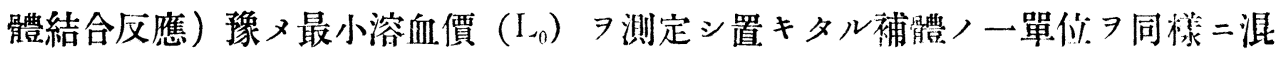
和シ良ク振湯混和セシメタル後 $37^{\circ} \mathrm{C}$ 八躬筐內二 1 時間放置入。此際抗血清,

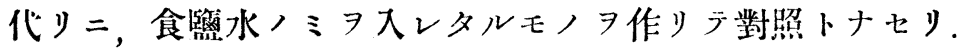

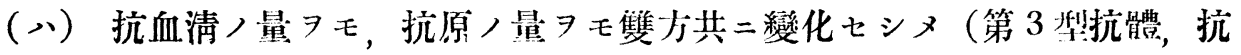
原補體結合反應）之レニ豫メ最小溶血價（．0） 7 测定シ置キタル補體ノ一單位

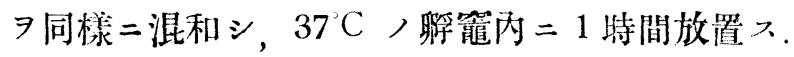

（二）次デ溶血素及ビ山羊血球食監水浮游液，規定セラレタル，一定量

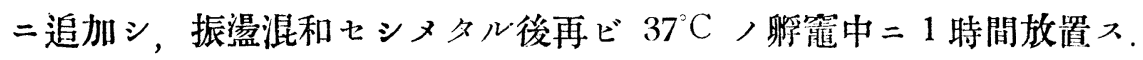

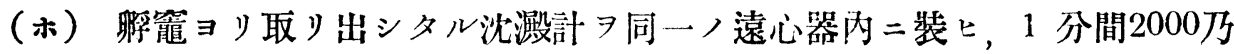
至2500廻轉二テ 20 分閏遠心沈澱七シム。

（へ）沈澱計，度目 ヨーペニテ檢シ不溶解二殘留シタル血球ノ容積 7 記上 ス. 沈澱計ノ一度月八容積ハ約 $0.0007 \mathrm{cc}+リ$. 又同特二全血球量 $(\mathrm{R}) \ni 100.0$ トナシタル垥合二於ケル各不溶解殘留血球量ノ 100 分比习求メタリ。而シテ者 沸先疫元原液，同透析內液及ビ透析外液ノ 3 抗原ノ抗原性能働力八判定二八面二八殘留血球量， 100 分比 $\ni$ 以テシ，他面二八殘留血球量ノ總和ョリ抗原抗 
體ノ夫々ノ單獨補體結合ニョル殘留血球量ノ總和 $コ$ 减ジタルノ, 即テ (抗原

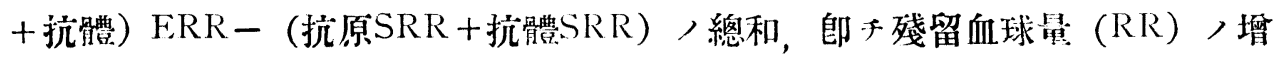
加ノ程度 (增强度) ヨ以テ比較セリ。

\section{第 4 章 容量的補體結合反隹檢查方法 ノ精密度ノ吟味}

\section{甲，抗體竝二㟟沸免疫元原液透析內液及七透析外液 ノ單獨 (SRR) 補體結合反隼}

一面腸ちふす菌惹沸隹疫元原液，透析內液及ビ透析外液 $夫$ 夫 $0.1 \mathrm{cc} ヨ$ ヨ $0.35 \mathrm{cc}$ 迄每回 $0.05 \mathrm{cc}$ 宛, 差 7 以于遞次增加七シメ, 各一列/沈搌計二配分シ 之レニョリ各々SRR ヨ求メ, 他面抗血清 $0.001 \mathrm{cc}$ 及ビ $0.002 \mathrm{cc}$ /ミノ各々單 獨補能結合反應 7 同時同列二試ミタル二其成績八第 1 表，第 2 表，第 3 表及ビ 第 1 圖ニ示サレタリ.

第 1 表 補體結合反應微量测定法, 精密度, 吟味 (SRR二 於ヶル抗原量ノ遞加卜RR量卜ノ關係）

（第10表及ビ第 1 圖參照）

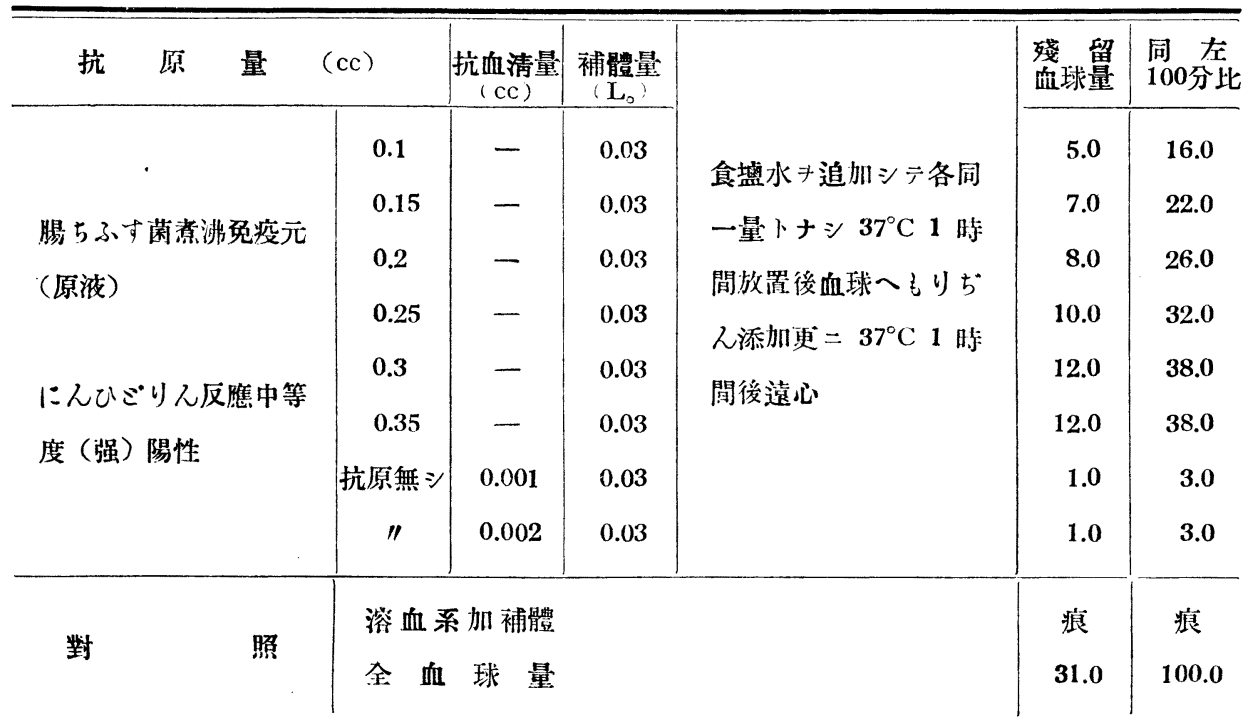


第 2 表 補體結合反應微量测定法, 精密度, 吟味 $(\mathrm{SRR}=$ 於ヶル抗原量ノ彪加トRR量卜ノ關係）

（第10表及ビ第 1 圖參照）

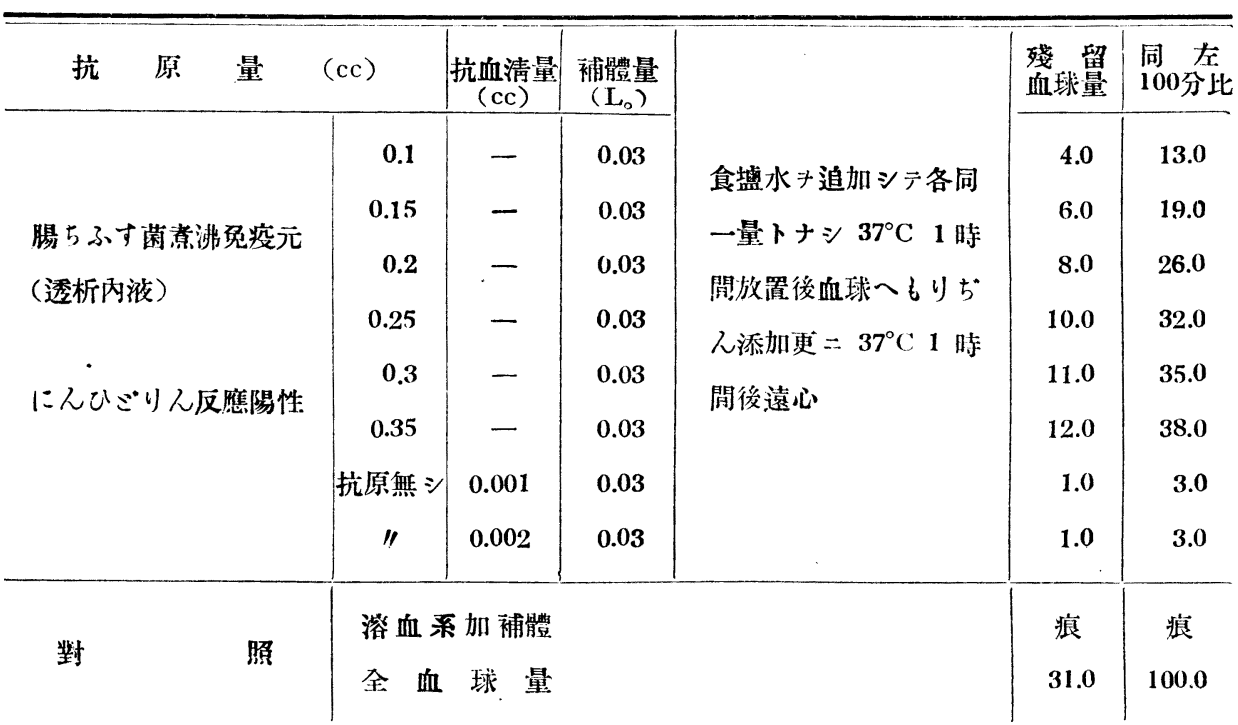

第 3 表 補體結合反應微量测定法, 精密度ノ吟味 (SRR二 於ヶル抗原量ノ彪加卜RR量卜八關係）

（第10表及ビ第 1 圖參照）

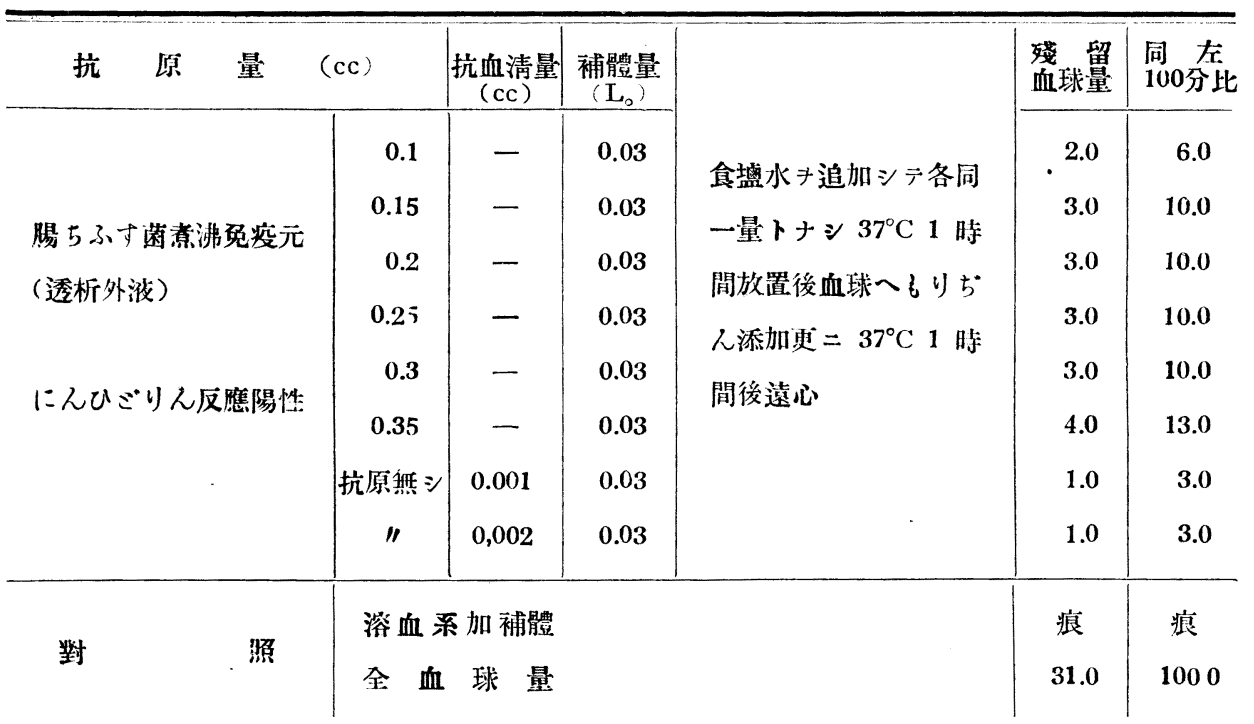


第 1 圖 腸古子す菌㟟沸㧤疫元（原液，透析內液及ビ透析外液）， 遞加卜 RR 量 100 分比卜，關係（第 1 表一第 3 表參照）

（1）單獨補體結合反應二就キテ（全血球量 31.0 補體量 L。0.03cc）

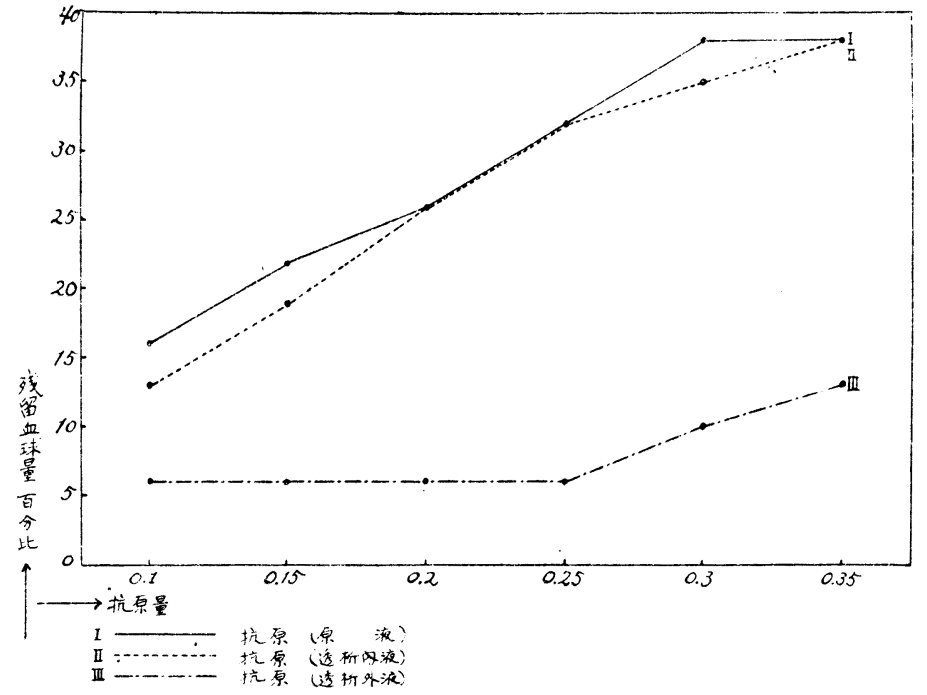

\section{所見}

(1) 抗血清 7 配 スル事ナク，抗原 量ノミ $\ni 0.1 \mathrm{cc} ヨ$ 》 $0.35 \mathrm{cc}$ 芞遞增七 シメタルニ惹沸免 疫元原液二於テ， 殘留血球量， 100 分比（第 1 表）、 $16.0,22.0,26.0$,

$32.0,38.0,38.0$ ᄏ示シ, 透析内液（第 2 表）二於テ、 $13.0,19.0,26.0,32 \cdot 0$, $35.0,38.0$ 卜現ハレタリ．即千抗原量ノ增加ト共二募沸免没元原液及ビ透析

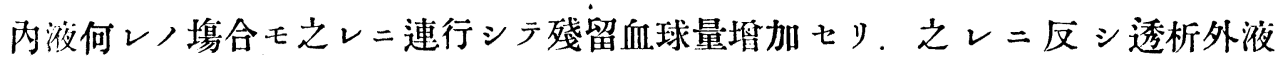
（第 3表）二於テン $6.0,10.0,10.0,10.0,10.0,13.0$ 示シ，抗原ノ遞加二 伴七，殘留血球量八著明ノ賭加习證明セザリキ。

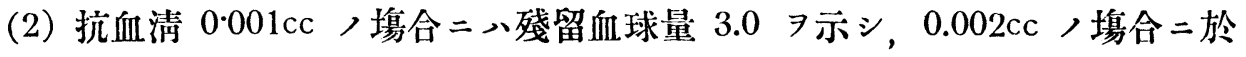
テモ等シク 3.0 ヨ示シタリ。（第 1 表，第 2 表及ビ第 3 表）.

（3）即于抗血清及ビ惹沸免疫元原液，透析內液及ビ透析外液/3抗原八單獨

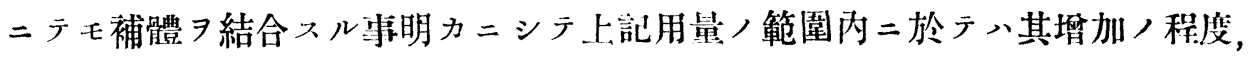

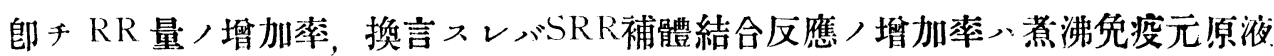
及ビ透析內液ニアリテハ殆ンド近似セル價 ヨ示シ，透析外液ニアリラハ前 2 抗 原二比シ極メテホナりキ（第 1 圖）

\section{乙. 㭟沸免疫元原液透析內液及七透析外液ノ 3 抗原ニテ ノ第 1 型抗體抗原結合 $(E R R)$ 二伝儿補體轺合反應}

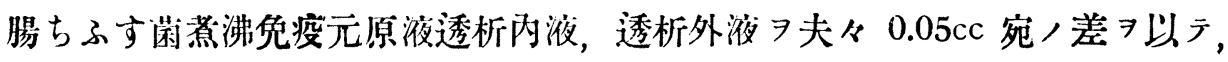


$0.1 \mathrm{cc} \exists リ 0.35 \mathrm{cc}$ 迄遞次增加セシメテ，次デ之二抗血清ノ一定量 $0.001 \mathrm{cc}$ 或、 $0.002 \mathrm{cc}$ 宛 7 加 , 同特同列 =補體結合反應 7 試ミタルニ其成績八第 4 表, 第 5 表，第 6 表，第 7 表，第 8 表，第 9 表及ビ第 2 圖ニ示サレタリ.

第 4 表 補體結合反應微量測定法, 精密度, 呤味 (ERR= 於ヶル抗原量ノ遞加トRR量卜ノ關係）

（第 10 表及ビ第 2 圖參照

\begin{tabular}{|c|c|c|c|c|c|c|c|}
\hline 原 & (cc) & $\mid \begin{array}{c}\text { 抗血清量 } \\
(\mathrm{cc})\end{array}$ & $\begin{array}{c}\text { 補體量: } \\
\left(\mathbf{L}_{0}\right)\end{array}$ & \multirow{7}{*}{$\begin{array}{l}\text { 食盍水キ追加シテ } \\
\text { 各同一量トナシ } \\
37^{\circ} \mathrm{C} 1 \text { 時間放置後 } \\
\text { 血球へもりちん添 } \\
\text { 加吏二 } 37^{\circ} \mathrm{C} 1 \text { 時 } \\
\text { 間後遠心 }\end{array}$} & 殘留 & $\begin{array}{l}\text { 同左 } \\
100 \text { 分比 }\end{array}$ & $\begin{array}{l}\mathrm{E} \mathrm{R} \mathrm{R} \\
\text { 八總和 }\end{array}$ \\
\hline \multirow{3}{*}{$\begin{array}{l}\text { 腸ち子、寸菌港沸免 } \\
\text { 疫元（原液） }\end{array}$} & 0.1 & 0.001 & 0.03 & & 11.0 & $35^{\circ} 0$ & \multirow{6}{*}{94.0} \\
\hline & 0.15 & 0.001 & 0.03 & & 13.0 & 42.0 & \\
\hline & 0.2 & 0.001 & 0.03 & & 16.0 & 51.0 & \\
\hline \multirow{3}{*}{$\begin{array}{l}\text { にんひミ゙りん反鷹 } \\
\text { 中等度(强)陽性 }\end{array}$} & 0.25 & 0.001 & 0.03 & & 17.0 & 54.0 & \\
\hline & 0.3 & 0.001 & 0.03 & & 18.0 & 58.0 & \\
\hline & 0.35 & 0.001 & 0.03 & & 19.0 & 61.0 & \\
\hline \multirow{2}{*}{ 對照 } & \multicolumn{3}{|c|}{ 溶血系加補體 } & & 痕 & 浪 & \\
\hline & \multicolumn{3}{|c|}{ 全 血 球 量 } & & 31.0 & 100.0 & \\
\hline
\end{tabular}

第 5 表 補體結合反應微量測定法, 精密度, 吟味 $(\mathrm{ERR}=$ 於ヶル抗原量ノ彪加ト RR 量トノ關係 （第 10 表及ビ第 2 圖參照）

\begin{tabular}{|c|c|c|c|c|c|c|c|}
\hline 原 & (cc) & $\begin{array}{c}\text { 抗血清量 } \\
(\mathrm{cc})\end{array}$ & $\begin{array}{c}\text { 補體量 } \\
(\mathrm{L} \text { 。) }\end{array}$ & \multirow{7}{*}{ 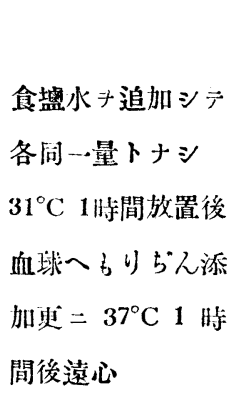 } & $\begin{array}{l}\text { 殘留 } \\
\text { 血球量 }\end{array}$ & $\begin{array}{l}\text { 同左 } \\
100 \text { 分比 }\end{array}$ & $\begin{array}{l}\mathrm{ER} R \mathrm{R} \\
\text { ノ總和 }\end{array}$ \\
\hline \multirow{3}{*}{ 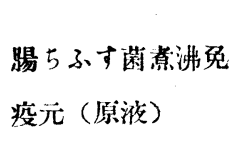 } & 0.1 & 0.002 & 0.03 & & 14.0 & 45.0 & \multirow{6}{*}{111.0} \\
\hline & 0.15 & 0.002 & 0.03 & & 16.0 & 51.0 & \\
\hline & 0.2 & 0.002 & 0.03 & & 18.0 & 58.0 & \\
\hline \multirow{3}{*}{$\begin{array}{l}\text { にんひミ゙りん反應 } \\
\text { 中等度(强)陽性 }\end{array}$} & 0.25 & 0.002 & 0.03 & & 19.0 & 61.0 & \\
\hline & 0.3 & 0.002 & 0.03 & & 22.0 & 70.0 & \\
\hline & 0.35 & 0.002 & 0.03 & & 22.0 & 70.0 & \\
\hline \multirow{2}{*}{ 對照 } & \multicolumn{3}{|c|}{ 溶血系加補體 } & & 痕 & 浪 & \\
\hline & \multicolumn{3}{|c|}{ 全 血 球 量 } & & 31.0 & 100.0 & \\
\hline
\end{tabular}


猪橧等述

(1907)

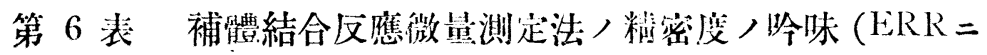

於ケル㧤原量ノ遞加トRR量卜ノ關係)

（第10表及ピ第 2 圖參照）

\begin{tabular}{|c|c|c|c|c|c|c|c|}
\hline 原 & (cc) & $\frac{\text { 挄血清量 }}{(\mathrm{cc})}$ & $\begin{array}{c}\text { 補體量 } \\
\text { L。 }\end{array}$ & \multirow{7}{*}{$\begin{array}{l}\text { 食盐水+追加シ } \\
\text { 各同一量トナシ } \\
37^{\circ} \mathrm{C} 1 \text { 時間放置後 } \\
\text { 血球一もりぢん添 } \\
\text { 加石二 } 37^{\circ} \mathrm{C} 1 \text { 時 } \\
\text { 間後迠心 }\end{array}$} & 残 留 & $\begin{array}{l}\text { 同 左 } \\
100 \text { 分比 }\end{array}$ & $\begin{array}{l}\mathrm{ERR} R \\
\text { 八總和 }\end{array}$ \\
\hline \multirow{3}{*}{$\begin{array}{l}\text { 腸ちふ寸菌港沸免 } \\
\text { 疫元（透析內液） }\end{array}$} & 0.1 & 0.001 & 0.03 & & 10.0 & 32.0 & \multirow{6}{*}{89.0} \\
\hline & 015 & 00 (j1 & 0.03 & & 130 & 430 & \\
\hline & 0.2 & 0.001 & 0.03 & & 14.0 & 45.0 & \\
\hline \multirow{3}{*}{$\begin{array}{l}\text { にんひごりん反應 } \\
\text { 晹性 }\end{array}$} & 0.25 & 0.001 & 0.03 & & 16.0 & 51.0 & \\
\hline & 0.3 & 0.001 & 0.03 & & 18.0 & 58.0 & \\
\hline & 0.35 & 0.001 & 0.03 & & 18.0 & 58.0 & \\
\hline \multirow{2}{*}{ 對照 } & \multicolumn{3}{|c|}{ 溶血系加 補能豊 } & & 瘫 & 痕 & \\
\hline & \multicolumn{3}{|c|}{ 全 血 球 量 } & & 31.0 & 100.0 & \\
\hline
\end{tabular}

第 7 表 補體結合反應微量测定法, 精密该, 呤味 (ERR二 於ケル秎原量ノ彪加卜RR量卜，關係）

（第 10 表及

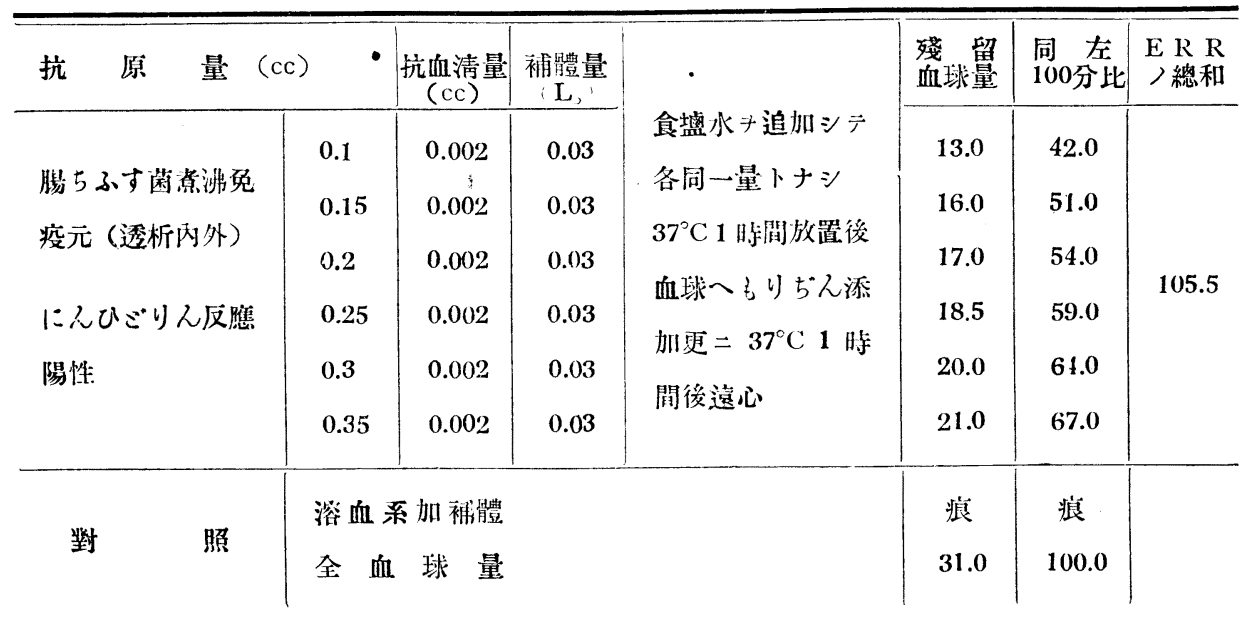


第 8 表 補體結合反應微量測定法, 精密度, 㢵味 $(\mathrm{ERR}=$ 於ケル抗原量, 彪加卜RR量卜ノ關係

（第 10 表及 ピ第 2 圖參照）

\begin{tabular}{|c|c|c|c|c|c|c|c|}
\hline 原 & (cc) & $\begin{array}{c}\text { 抗向淸量 } \\
\text { (cc) }\end{array}$ & $\begin{array}{c}\text { 補體量 } \\
\left(\mathrm{L}_{2}\right)\end{array}$ & \multirow{7}{*}{ 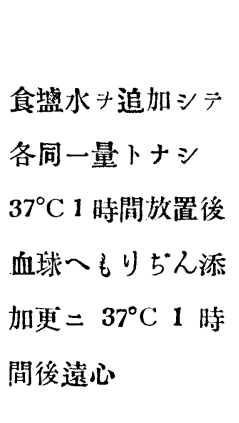 } & 殘留 & $\begin{array}{l}\text { 同左 } \\
100 \text { 分比 }\end{array}$ & $\begin{array}{l}\text { E R R R } \\
\text { ノ總和 }\end{array}$ \\
\hline \multirow{3}{*}{$\begin{array}{l}\text { 腸亏ふ寸囷煮沸免 } \\
\text { 疫元（透析外液） }\end{array}$} & 0.1 & 0.001 & 0.03 & & 2.0 & 6.0 & \multirow{6}{*}{14.0} \\
\hline & 0.15 & 0.001 & 0.03 & & 20 & 6.0 & \\
\hline & 0.2 & 0.001 & 0.03 & & 2.0 & 6.0 & \\
\hline \multirow{3}{*}{$\begin{array}{l}\text { にんひミ゙りん反隹 } \\
\text { 陽性 }\end{array}$} & 0.25 & 0.001 & 0.03 & & 2.0 & 6.0 & \\
\hline & 0.3 & 0.001 & 0.03 & & 3.0 & 10.0 & \\
\hline & 0.35 & 0.001 & 0.03 & & 3.0 & $10 \cdot 0$ & \\
\hline \multirow{2}{*}{ 對照 } & \multicolumn{3}{|c|}{ 溶血系加補體 } & & 浪 & 痕 & \\
\hline & \multicolumn{3}{|c|}{ 全 血 球 量 } & & 31.0 & 100.0 & \\
\hline
\end{tabular}

第 9 表 補體結合反應微量測定法, 精密度, 呤味 $(\mathrm{ERR}=$ 於ヶル抗原量，彪加卜RR量卜，關係）

（第 10 表及ビ第 2 圖參照）

\begin{tabular}{|c|c|c|c|c|c|c|c|}
\hline 抗 & (cc) & $\begin{array}{c}\text { 抗血清量 } \\
(\mathrm{cc})\end{array}$ & $\begin{array}{c}\text { 補體量 } \\
\left(\mathrm{L}_{0}\right)\end{array}$ & $\bullet$ & $\begin{array}{l}\text { 殘留 } \\
\text { 血球 }\end{array}$ & $\begin{array}{l}\text { 同 左 } \\
100 \text { 分比 }\end{array}$ & $\begin{array}{l}\mathrm{E} R \mathrm{R} \\
\text { 八總和 }\end{array}$ \\
\hline \multirow{3}{*}{$\begin{array}{l}\text { 腸ちふす囷乽沸免 } \\
\text { 疫元（透析外滩） }\end{array}$} & 0.1 & 0.002 & 0.03 & 艮盟水子追川シテ & 2.0 & 6.0 & \multirow{6}{*}{17.0} \\
\hline & 0.15 & 0.002 & 0.03 & 各问一重トナジ & 2.0 & 6.0 & \\
\hline & 0.2 & 0.002 & 0.03 & 3rC1時間放直後 & 2.0 & 6.0 & \\
\hline にんぴミ゙りん反應 & 0.25 & 0.002 & 0.03 & 血球へもり & 3.0 & 10.0 & \\
\hline \multirow[t]{2}{*}{ 陽性 } & 0.3 & 0.002 & 0.03 & & 4.0 & 13.0 & \\
\hline & 0.35 & 0.092 & 0,03 & & 4,0 & 13.0 & \\
\hline \multirow{2}{*}{ 嵵照 } & \multicolumn{3}{|c|}{ 溶血系加補體 } & & 痕 & 痕 & \\
\hline & \multicolumn{3}{|c|}{ 全血 球 量 } & & 31.0 & 100.0 & \\
\hline
\end{tabular}


第 2 圖 腸ちふす菌募沸先疫元（原液，透析内液及ビ透析外液），

遞加卜 RR 量 100 分比卜八關係（第 4-9 表參照）

（2）抗原加抗血清補體結合反應二就キテ（第 1 型補體結合反應）

全血球量 31.0 補體量 ( L。0.03cc)

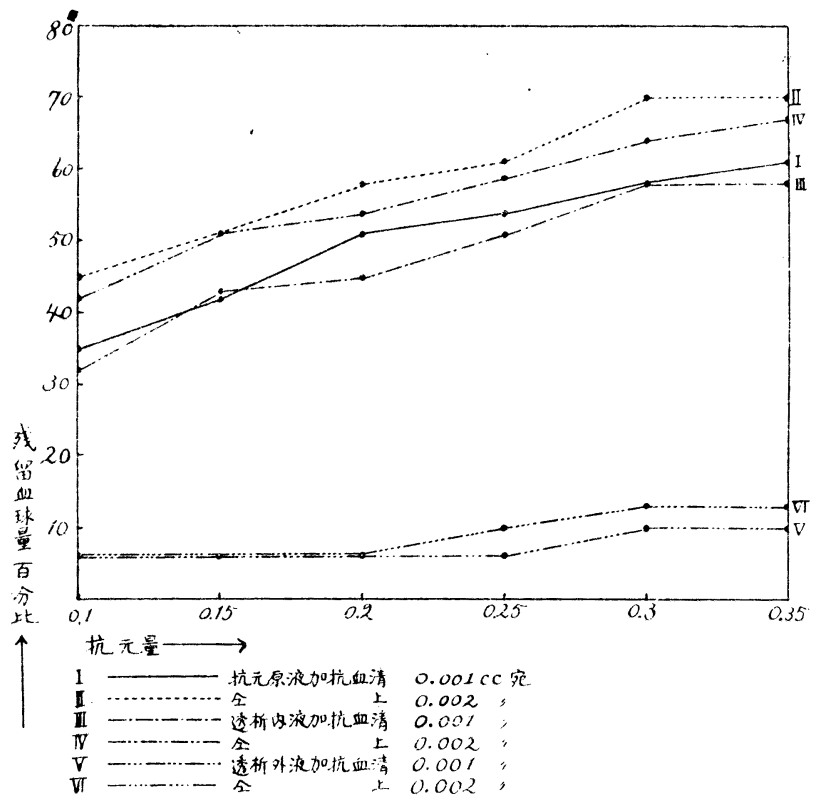

所見

(1) 抗血清 7 一定 $(0.001 \mathrm{cc}$ 或 $20.002 \mathrm{cc})$ トナシ, 抗原量 $70.1 \mathrm{cc}$ ヨリ $0.35 \mathrm{cc}$ 迄 $0.05 \mathrm{cc}$ 宛 ノ差习以テ彪加セシメ タル二者沸㷛疫元原液 二テ八残留血球量， 100 分比八抗血清 0.001 cc（第 4 表）ニアリテ 八 $35.0,42.0,51.0$, $54.0,58.0,61.0, \exists$ 示

シ，抗血清 $0.002 \mathrm{cc}$ (第 5 表） ニアリテハ 45.0,51.0, 58.0,61.0,70.0,70.0 ヨ示シ, 透析內液; 㰾合八抗血清 $0.001 \mathrm{cc}$ (第 6 表) ニアリテハ $32.0,43.0$. $45.0,51.0,58.0,58.0$ ヨ示シ，抗血清 $0.002 \mathrm{cc}$ (第 7 表）二アリテハ42.0, $51.0,54.0,59.0,64.0,67.0$ ヨ示シ, 而シテ透析外液ノ堭合、抗血清 $0.001 \mathrm{cc}$ （第 8 表）ニアリテハ $6.0,6.0,6.0,6.0,10.0,10.0$ 示シ，抗血清 $0.002 \mathrm{cc}$ （第 9 表） 合モ特二者沸免疫元原液，及ビ透析內液二テハ抗原量，遞加二件七，殘留血球 量モ著明二增加シタリ。之レニ反シ透析外液，㙋合、僅少ナル殘留血球量 7 示 スニ過ギザリキ。

（2）郎チ煮沸免疫元原液乃至ハ透析内液ヨ抗原トシタル㰾合， RR 量、毎常 相接近セル價 ヨ示シ, 透析外液 ヨ抗原トルタル晧合ノ RR 量ヨリ飞該用量ノ範 圍內二於テハ常ニ比較ニナラザル程大ナリキ。（第 2 圖） 


\section{丙. 所見總括及ビ考察}

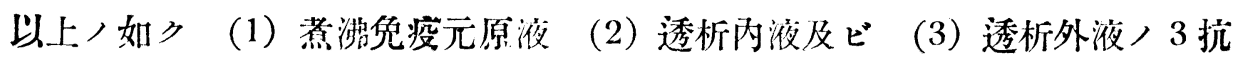
原液ヨ以ラセル單獨 (SRR) 及ビ抗體抗原結合 $(\mathrm{ERR})$ 二依ル補體結合反應， 成績 アー目瞭然タラシメンガタヌニ更二概括表示スレバ第10表 $コ$ 得べシ.

第 10 表 腸ちふす菌惹沸免疫元（原液）同透析內液及ビ透析外 液 $习$ 以テヶル抗原, 抗血清 SRR下抗血清加抗原 ERR トノ差 (ERR補體結合反應二於ケル RR，增加）

\begin{tabular}{|c|c|c|c|c|}
\hline & \multirow{2}{*}{ 抗 原 種 別 } & \multicolumn{3}{|c|}{ 腸5子寸菌竟沸免疫元 } \\
\hline & & 液 & 透析內液 & 透析外诉 \\
\hline (I) & 抗 原 (SRR) ）總 和 & 54.0 & 51.0 & 18.0 \\
\hline (II) & 抗血淸 0.001 (SRR) $\times 6$ & 6.0 & 6.0 & 6.0 \\
\hline (III) & 抗血清 0.002 (SRR) $\times 6$ & 6.0 & 6.0 & 6.0 \\
\hline (IV) & SRR （IトII卜ノ總和） & 60.0 & 57.0 & 24.0 \\
\hline$(V)$ & SRR （Iト正卜ノ總和） & 60.0 & 57.0 & 24.0 \\
\hline (V) & 抗原加抗血清 0.001 (ERR) 總和 & 94,0 & 89.0 & 14.0 \\
\hline ( VII) & 抗原加抗血清 0.002 (ERR) ) 總和 & 111.0 & 105.5 & 17.0 \\
\hline (证) & 補體結合反應陽性程度㒄强度 ( $\mathrm{U}-\mathbb{I}$ ) & 34.0 & 32.0 & -10.0 \\
\hline$(\mathbb{X})$ & 補體結合反應陽性程度(掏强度) $(\mathrm{VI}-\mathrm{V}$ ) & 51.0 & 48.5 & -7 \\
\hline
\end{tabular}

第 10 表二明示セラレタル結果ョリシテ, 空量的補體結合反應檢查ノ精密度 吟味スル二募沸免疫元原液及ビ透析液, 抗原抗體結合二依ル補體結合反應， 殘留血球量八兩抗原個タ>單獨補體結合反應ノ殘留血球量〉和ヨリモ大ナルコ ト, 郎チ扰體, 抗原結合ニョリ殘留血球量ノ增加ヨ來タセルコトフ認メ得心シ 此ノ所見 7 式ニテ表示スレバ次ノ如シ.

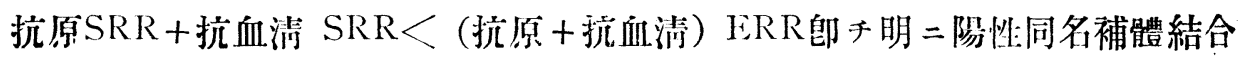
反應郎于 ERR ヨ指示スルモノト云ハザルベカラズ，如何トナレバ抗體抗原結 合ニョル補體結合力（RR）ノ方ガ抗體卜抗原トソレゾレ單獨二行ハレタル補 體結合力八和ョリモ大ナルモノタルコト明白二立證セラレタルガ故ナリ．而シ ラ兩者何レノ抗原ノ㰾合モ抗原量ノ遞加卜共 $=R R$ 量入漸 シコト第 1 圖及ビ第 2 圖ニョリ明ナリ。每每常煮抗免疫元原液 ヨ以テノ補蹬結 
合反應陽性程度入透析内液ヨ以テノソレヨ倰嘿セリ。然レドモ其凌駕セル程度

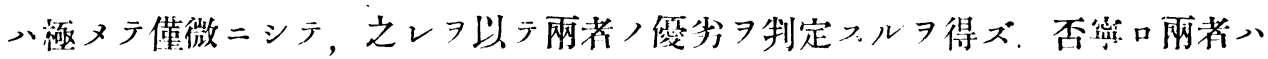
伯仲ノ間ニアリト謂ツバシ.

透析外液. 抗原トセル塲合ニアリテハ第10表二依リテ明白ナルガ如ク二，抗 原加抗血清ニョル RR 量ノ增强度（郎チ補體補體結合反應陽性程度）八全ク立 證セラレザルノミカ却テ負數ヨ示シタリ。換言スレバ補體結合反應ハ陰性ヨ意 味スルモノナリ。而シテ抗原量ハ夫々彪加セラレタルモRR 量ノ連行增大心極 メテ少弱ニ過ザリキ（第 1 圖及ビ第 2 圖參照）.

以上/如キ容量的補體結合反應檢查，換言スレバ ERR 反應ノ結果、募沸侁 疫元ノ主體がにんひどりん反應性物質ニアリャノ制定二向ッテ極メテ明確ナル

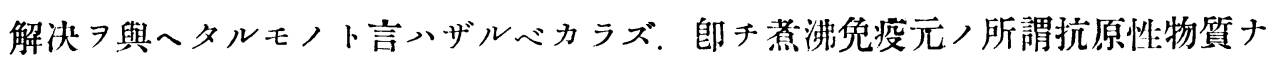
ルモノハころじーむ囊ヨ全然透析シ得サルモノナリ．具兴にんひどりん應性

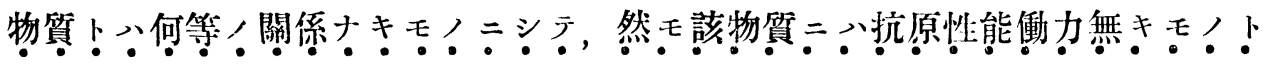

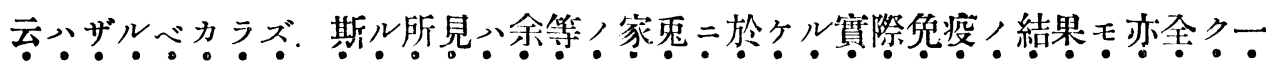

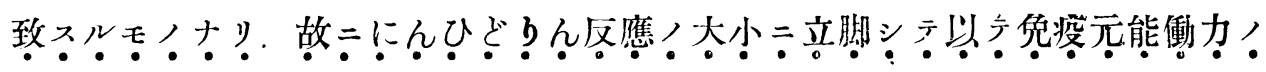

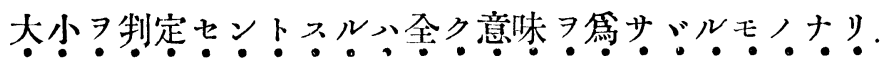

\section{第 5 童 容景的禣體結合反應檢查方法ノ精密度ノ 吟味(第 2 型抗體抗原結合ニヨル補體結合反應)}

\section{甲，單獨補體䊅合反應 (SRR)}

抗腸ちふす菌家鬼血清 $70.001 \mathrm{cc} ヨ$ ヨ $0.0035 \mathrm{cc}$ 迄每回 $0.0005 \mathrm{cc}$ 宛，差. テ彪次增量セシメ，沈澱計二配分シ，之二ヨリ各々SRR ヨ求メ，同特二又者 沸免疫元原液透析内液及ビ透析外液, 3 抗原, 各々 $0.05 \mathrm{cc}$ 單獨補體結合反應 (SRR) ヨ行ヒタリ。實驗成績八第11表ニ示サレタリ。 
第 11 表 補體結合反應微量测定法, 精密度, 呤味 (SRR二 於ヶル抗血清, 遞加卜 RR 量卜ノ關係)

(第15表參照)

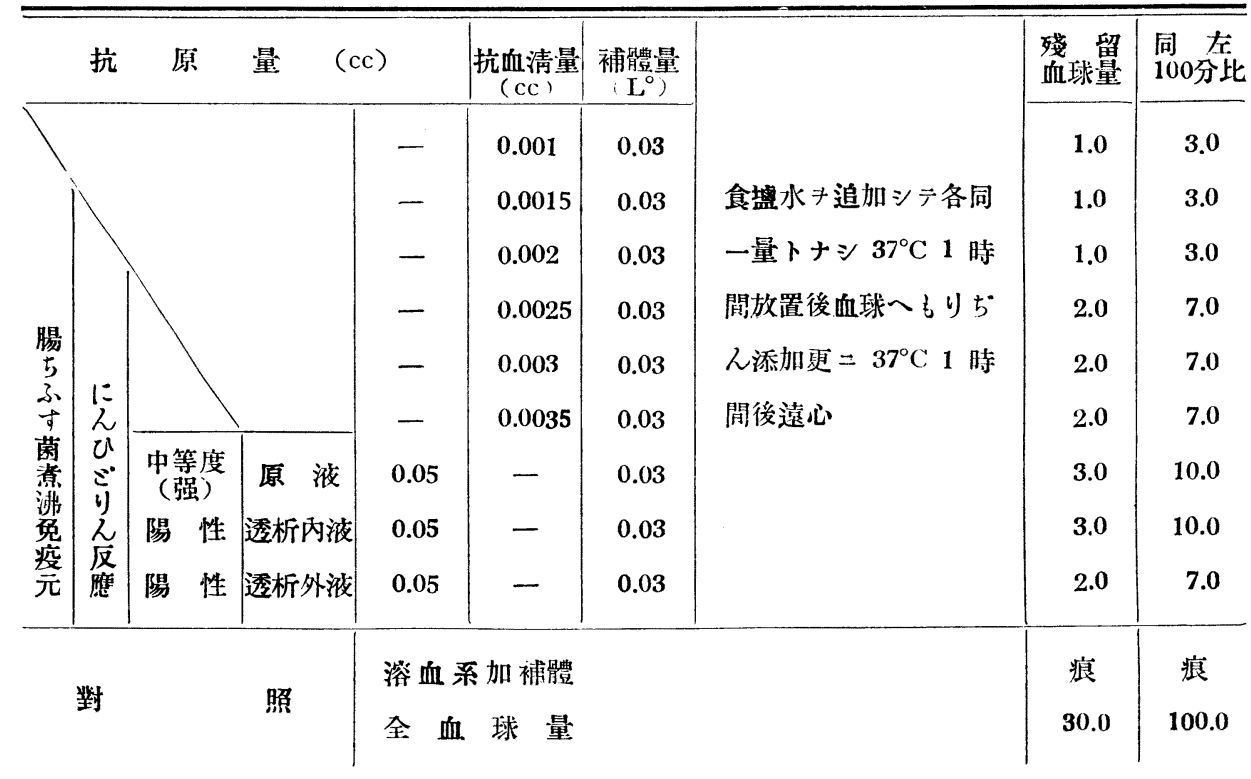

\section{所見}

（1）抗血清，單獨補體結合反應二於テ，抗血涌 $尹 0.001 \mathrm{cc} ヨ$ ヨ $0.0035 \mathrm{cc}$ 迄

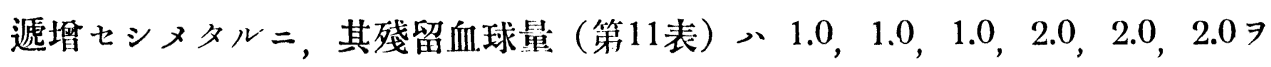
來シ, 其總和八 9.0 ヨ示シ留り。

（2）者沸免疫元原液 $0.05 \mathrm{cc}=$ テノ殘留血球量、 3.0 透析内液ニアリテハ3.0 透析外液ニアリテハ2.0 ヨ示シタリ（第11表）郎チ原液及ビ透析内液ノSRR， 相等シク透析外液, SRR ヨリモ大ナリキ.

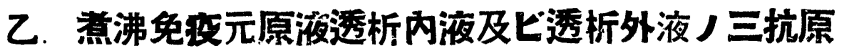 抗體結合ニヨル補體給合反隹 (ERR)}

腸ちふす菌煮沸先疫元原液透析內液及ビ透析外液各々 $0.05 \mathrm{cc}$ 宛 $ᄏ$ 各々一列 ノ沈澱計二配分シ，此等二直チ二抗血清 $尹 0.001 \mathrm{cc} ヨ$ ヨ $0.0035 \mathrm{cc}$ 迄遞次增量 シテ, 涯加シ, 抗原, 抗體結合 $ニ ョ ル$ 補體結合反應 $(\mathrm{FRR}) \ni$ 檢查シタルニ, 其結果ハ第 12 表，第13表，第 14 表及ビ第 3 圖ニ示サレタリ. 
猪木隆背述

(1913)

第 12 表 補體結合反應微量測定法, 精密度, 呤味 $(\mathrm{ERR}=$ 於ケル抗血清, 遞加卜 RR 量卜ノ關係)

（第15表及ビ第 3 圖參照）

\begin{tabular}{|c|c|c|c|c|c|c|c|}
\hline 原 & (cc) & $\mid \begin{array}{c}\text { 抗血清量 } \\
\text { (cc) }\end{array}$ & $\begin{array}{c}\text { 補體量 } \\
(\mathrm{L})\end{array}$ & 食啮水垖加シテ & $\begin{array}{l}\text { 殘留 } \\
\text { 血球量 }\end{array}$ & $\begin{array}{l}\text { 同左 } \\
100 \text { 分比 }\end{array}$ & $\begin{array}{l}\mathrm{ERR} R \\
\text { ノ總和 }\end{array}$ \\
\hline \multirow{2}{*}{$\begin{array}{l}\text { 晹 } 5 \text { 小寸菌㝸沸免 } \\
\text { 疫元（原淮） }\end{array}$} & 0.05 & 0.001 & 0.03 & 各同一量トナシ & 7.0 & 23.0 & \multirow{6}{*}{67.0} \\
\hline & 0.05 & 0.0015 & 0.03 & $37^{\circ} \mathrm{C} 1$ 時間放置後 & 9.0 & 30.0 & \\
\hline \multirow{4}{*}{$\begin{array}{l}\text { にんひミ゙りん反應 } \\
\text { 中等度 (强) 晹性 }\end{array}$} & 0.05 & 0.002 & 0.03 & 血球へもり り゙ん添 & 11.0 & 36.0 & \\
\hline & 0.05 & 0.0025 & 0.03 & 加更 $=37^{\circ} \mathrm{C} 1$ 時 & 12.0 & 40.0 & \\
\hline & 0.05 & 0.003 & 0.03 & 間後遠心 & 13.0 & 43.0 & \\
\hline & 0.05 & 0.0035 & 0.03 & & 15.0 & 50.0 & \\
\hline \multirow{2}{*}{ 對 } & \multicolumn{3}{|c|}{ 溶血系加補體 } & & 痕 & 痕 & \\
\hline & \multicolumn{3}{|c|}{ 全 血 球 量 } & & 30.0 & 100.0 & \\
\hline
\end{tabular}

第 13 表 補體結合反應微量测定法, 精密度, 呤味 (ERR二 於ヶル抗血清ノ彪加トRR 量トノ關係）

（第15表及ビ第 3 圖參照）

\begin{tabular}{|c|c|c|c|c|c|c|c|}
\hline 抗 & (cc) & $\mid \begin{array}{c}\text { 抗血清量 } \\
(\mathrm{cC})\end{array}$ & $\begin{array}{c}\text { 補體量 } \\
\left(L_{0}\right)\end{array}$ & 食盐水头追加シテ & $\begin{array}{l}\text { 殘留 } \\
\text { 血球量 }\end{array}$ & $\begin{array}{l}\text { 同 左 } \\
100 \text { 分比 }\end{array}$ & $\begin{array}{l}\mathrm{ER} R \mathrm{R} \\
\text { ノ總和 }\end{array}$ \\
\hline 腸5 子寸菌堂沸免 & 0.05 & 0.001 & 0.03 & 各同一量トナシ & 6.0 & 20.0 & \multirow{6}{*}{64.0} \\
\hline 疫元 (透析內液) & 0.05 & 0.0015 & 0.03 & $37^{\circ} \mathrm{C} 1$ 時間放置後 & 8.0 & 26.0 & \\
\hline & 0.05 & 0.002 & 0.03 & 血球一もりぢん添 & 9.0 & 30.0 & \\
\hline にんひミ゙りん反應 & 0.05 & 0.0025 & 0.03 & 加更二 $37^{\circ} \mathrm{C} 1$ 時 & 12.0 & 40.0 & \\
\hline \multirow[t]{2}{*}{ 晹泩 } & 0.05 & 0.003 & 0.03 & 問後遠心 & 14.0 & 46.0 & \\
\hline & 0.05 & 0.0035 & 0.03 & & 15.0 & 50.0 & \\
\hline \multirow{2}{*}{ 對照 } & \multicolumn{3}{|c|}{ 溶血系加補體 } & & 痕 & 痕 & \\
\hline & \multicolumn{3}{|c|}{ 全 血 球 量 } & & 30.0 & 100.0 & \\
\hline
\end{tabular}


第 14 表 赤體結合反應微量測定法, 精密度, 吟味 $(\mathrm{ERR}=$ 於ヶル抗血清，彪加トRR 量トノ關係）

（第15表及ビ第 3 圖參照）

\begin{tabular}{|c|c|c|c|c|c|c|c|}
\hline 原 & $(\mathrm{cc})$ & 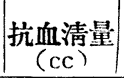 & $\begin{array}{c}\text { 補體量 } \\
\left(\mathrm{L}_{0}\right)\end{array}$ & 食墭水头追加シ & $\begin{array}{l}\text { 残留 } \\
\text { 血球量 }\end{array}$ & $\begin{array}{l}\text { 同 左 } \\
100 \text { 分比 }\end{array}$ & $\begin{array}{r}\mathrm{ERR} R \\
\text { 一總和 }\end{array}$ \\
\hline 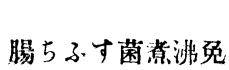 & 0.05 & 0.001 & 0.03 & 各闰一量卜ナシ & 2.0 & 7.0 & \multirow{6}{*}{14.0} \\
\hline 疫元 (透析外液) & 0.05 & 0.0015 & 0.03 & $37^{\circ} \mathrm{C} 1$ 時間放置後 & 2.0 & 7.0 & \\
\hline & 0.05 & 0.002 & 0.03 & 血球へもり & 2.0 & 7.0 & \\
\hline にんひミ゙りん反應 & 0.05 & 0.0025 & 0.03 & 加更 $=37^{\circ} \mathrm{C} 1$ 時 & 2.0 & 7.0 & \\
\hline \multirow[t]{2}{*}{ 婸性 } & 0.05 & 0.003 & 0.03 & 間後遠心 & 3.0 & 10.0 & \\
\hline & 0.05 & 0.0035 & 0.03 & & 3.0 & 10.0 & \\
\hline \multirow{2}{*}{ 對照 } & \multicolumn{3}{|c|}{ 溶血系加補體 } & & 痕 & 痕 & \\
\hline & \multicolumn{3}{|c|}{ 全 血 球 量 } & & 30.0 & 100.0 & \\
\hline
\end{tabular}

第 3 圖腸ちふす菌者沸免疫元（原液透析內液及ビ透析外液）各 $0.05 \mathrm{cc}$ 添加及ビ抗血清, 遞加ト RR 量 100 分比ト八關係 （第12一第14表參照）（第 2 型補體結合反應二就キテ）

全血球量 30.0 補體量 $\mathrm{L}_{0} 0.03 \mathrm{cc}$

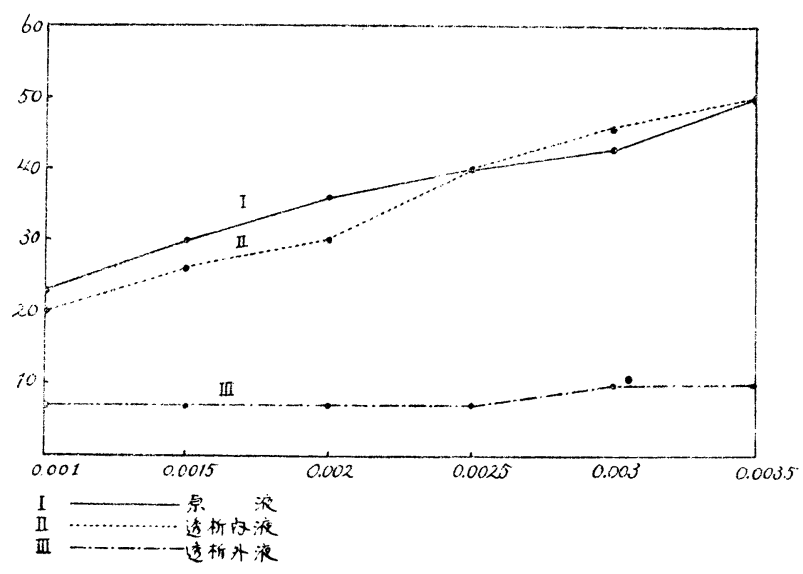

所見

（1）薏沸免疫元原液 $(0.05 \mathrm{cc})=$ 就テ行ヒタ ル抗體抗原結合 $ニ ヨ ル$ 補體結合反應八抗血清 $\exists 0.001 \mathrm{cc} \exists$ リ $0.0035 \mathrm{cc}$ 迄彪次增量スル 上，殘留血球量、 7.0 乃至 15.0 ヨ示シ，其總和、67.0 ニシテ，此際實驗甲二於ケル抗原 SRR ト抗血 清 SRRト，和 27.0 ヨモモ著明二增加シタリ。郎チ抗原ト抗血清ノ混和物ニテ 
結合セルダケノ補體ノ正味ノ價 $\mathrm{RR}$ 量ニテ示セバ $3.0,5.0,7.0,7.0,8.0$ 10.0 ニシテ其總和、40.0トナリタリ（第12表）

（2）透析内液 $(0.05 c c)$ 二就テ行ヒタル抗體, 抗原結合ニヨル補體結合反應

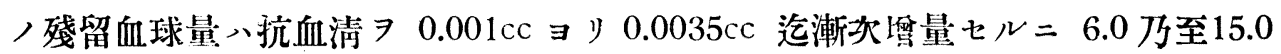

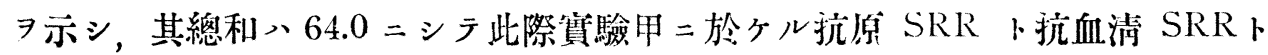
ノ和 $27.0 モ ヨ リ モ$ 著明二增加シタリ。毁チ抗原卜抗血清ノ混和物ニテ結合セル ダケノ補體ノ正味ノ價 $7 \mathrm{RR}$ 量ニテ示セバ, $2.0,4.0,5.0,7.0,9.0,10.0$ 二シ テ其總和ハ37.0トナリタリ。（第13表）

（3）透析外液 $(0.05 c c)$ 二就キテ行ヒタル抗體, 抗原結合ニョル補體結合反

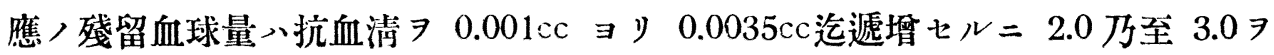
示シ，其總和八 14.0 ニシテ，反ッテ實驗甲二於ケル抗原 SRR ト抗血清SRRト

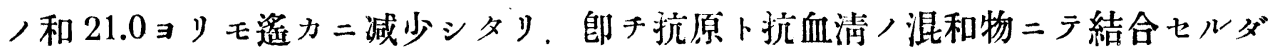
ケノ補體ノ正味 7 RR 量ニテ示セバ負數 1.0 , 負數 1.0 , 負數 2.0 , 負數 1.0 , 負數 1.0 , 負數 1.0 二シテ其總和 負數 7.0 ナリキ.（第14表）

（4）郎チ FRR 補體結合二於テモ者沸免疫元原液ニテノ殘留血球量八透析內 液ニテノ殘留血球量ト略々相接近シ，其總和ハ67.0 對 64.0 トフ僅少ノ差 示シタリ，ERR補體結合ノ結果トシテ，抗原，㿠血清個ィノ示シタルSRR， 和ヨリモ增加シタルダケノ RR 量 $\ni$ 比較七ル二煮沸㑆疫元ニテハ 40.0 ナル二對 シ透析内液二テ 37.0 、ニシテ其差僅カニ 3.0 ナリキ. 之レニ反シ透析外液 リテハ全然ERR 補體結合反應ノ型式 タリ.

\section{丙所見䘽括及比考察}

以上者沸免疫元原淮，透析內液及ビ透析外液ノ 3 抗原ニョル SRRERR ノ成 績 ヨ一目瞭然タラシメンガタメ二更二概括表示シテ第 15 表 $习$ 得タリ. 
第 15 表 抗䐪ちふす菌家鬼血清及ビ腸ちふす菌者沸货疫元 (原液)同透析內液透析外液 $习$ 以テセル抗原, 抗血 清 SRR r抗血清加抗原 ERR ト八差 (ERR 補體 結合反應二於ヶル $\mathrm{RR}$ ノ增加）

\begin{tabular}{|c|c|c|c|c|}
\hline & & \multicolumn{3}{|c|}{ 腸5 子す菌潦沸免疫元 } \\
\hline & & 原液 & 透析內液 & 透析外液 \\
\hline ( J ) & 抗 血 清 (SSR) ノ總 和 & 9.0 & 9.0 & 9.0 \\
\hline$(\pi)$ & 抗 原 0.05 (SRR) $\times 6$ & 18.0 & 18.0 & 12.0 \\
\hline (III) & $\operatorname{SRR}(I$ トII）和） & 27.0 & 27.0 & 21.0 \\
\hline (IV) & 抗原加抗血淸 (ERR) > 總和 & 67.0 & 64.0 & 14.0 \\
\hline$(\nabla)$ & 補體結合反應陽性程度、增强度) (IV-亚) & 40.0 & 37.0 & -7.0 \\
\hline
\end{tabular}

（1）煮沸先疫元原液及ビ透析內液ノ兩抗原，抗掯結合ニヨル補體結合反應，

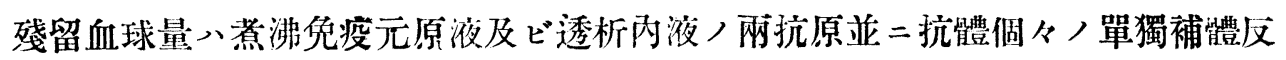

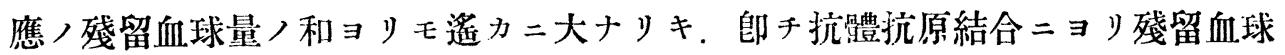

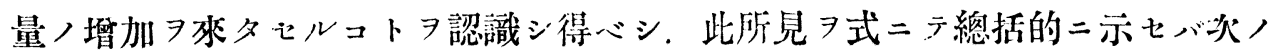
如シ.

税原 $\mathrm{SRR}+$ 抗血清 $\mathrm{SRR}<$ (抗原十抗血清) ERR

（2）者沸先疫元原液抗原，抗體結合 $ニ ョ ル$ 補體結合反應殘留血球量／增加度 、透析丙液抗原抗䯠結合 僅カニ大ナリキ。換言スレバ㒳抗原ノ抗原性能働力ニ格段ノ差暴 7 認メザリ キ. 此所見 式ニテ示セバ次ノ如シ.

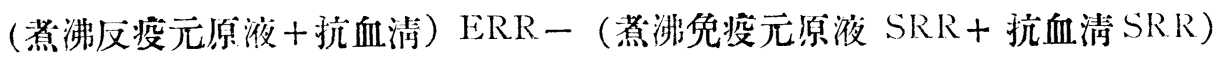

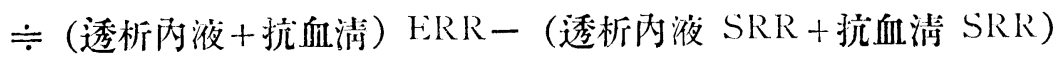

而シテ實驗，差額八僅カニ 3.0 , RR 量ナリキ.

(3) 透析外液抗原抗體結合ニョル補體結合及應,殘留血球量、抗原及ビ抗體 ノ個々八單獨補體結合反碓, 殘留血球ノ和ョリモ遙カニ少ナリキ。即キ抗體, 抗原結合ニョリ殘留血球量ノ增加ヨ示サベリキ，換言スレバ陽性ノ補體結合反 應ハ痕跡ダモ立證スル事ヨ得ズ却テ負數 7.0 タ示シタリ。

此所見 $习$ 式ニテ示セバ次ノ如シ. 
(透析外液十抗血清) $\mathrm{ERR}=14.0<($ 透析外液 $\mathrm{SRR}+$ 抗血清 $\mathrm{SRR}$ ) $=21.0$

（4）斯ノ如キ事實、煮沸免疫元〉且個抗原性物質、果シテ何物ナルカヨ極又

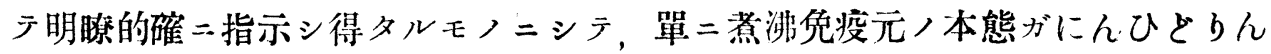
反應性物質ニアルトスルナラバにんひぞりん反應习殆ンド本等二保有フル透析 內液及ビ透析外㳸、又等シク抗體抗元結合ニヨル補體結合力八增强 7 明白二立 證スベキハ當然つ理ナリ，然レドモにんひに゙りん反應物質二透析外液二於テハ 抗原加抗體ニョルRR 量ノ增强度、全ク立證セラレザルノミカ, 却テ負數 シタリ。換言スレバ補體結合反應、陰性トナリタリ。而カモ透析內液 ヨ以テノ

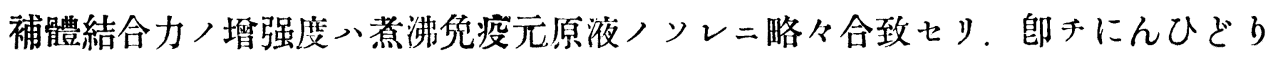
ん反應性物質、煮沸免疫元，抗原州物質主體卜ハ全ク無關係ナルモノニシテ，

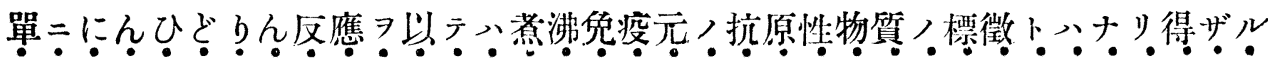
モ!!斷言セザルベカラズ.

\section{第 6 章 三抗原, 單獨補體䊅合前二第 3 型抗體, 抗原結合二依ル禣體結合反應二對スル影響}

晹ちふ寸菌者沸先疫元原液同透析內液及ビ同透析外液

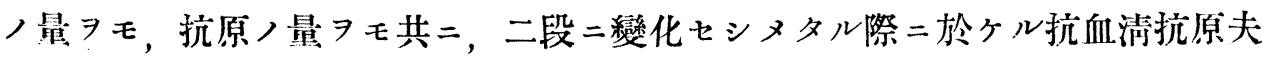

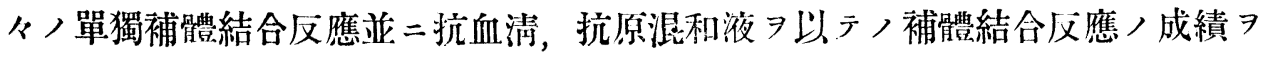
求メタル二第16表，第17表及ビ第18表ノ成績 7 得タリ.

第 16 表腸ちふす菌募沸先疫元(原液)乃至抗血清，單獨補 體結合反應並二兩者 7 以とル第 3 型乙補體結合反 應（にんびぞりん反應中等度(强)陽性）

\begin{tabular}{|c|c|c|c|c|c|c|c|c|}
\hline \multirow{2}{*}{ 抗原種別 } & \multirow{2}{*}{$\frac{\text { 抗原量 }}{(\mathrm{cc})}$} & \multirow{2}{*}{ 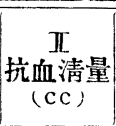 } & \multicolumn{3}{|c|}{ 單獨補體結合ニヨル殘留血球量 } & \multicolumn{2}{|c|}{$\begin{array}{l}\text { 抗原加抗血清補體結 } \\
\text { 合 } \\
\text { 淺留血琲竟 }\end{array}$} & \multirow{2}{*}{$\frac{\text { 增强度 }}{\text { TV-亚 }}$} \\
\hline & & & $\mathrm{S} \mathrm{T}_{\mathrm{R}}$ & $\begin{array}{ll}\pi \\
\mathrm{S} R \mathrm{R}\end{array}$ & $\begin{array}{c}\mathrm{S} \\
(I \mathbb{I})^{\mathrm{R}} \text { ) 總和 III }\end{array}$ & $\begin{array}{l}I+\mathbb{I} \\
\text { ERR }\end{array}$ & $\begin{array}{l}\mathrm{E} R \mathrm{R} / \\
\text { 總 和 IN }\end{array}$ & \\
\hline \multirow{4}{*}{$\begin{array}{l}\text { 晹七子寸菌堂 } \\
\text { 沸免疫元（原 } \\
\text { 湤） }\end{array}$} & 0.05 & 0.001 & 3.0 & 1.0 & 28.0 (抗原) & 6.5 & 54.5 （抗原 & 26.5（補 \\
\hline & 0.05 & 0.003 & 3.0 & 2.0 & ミト抗血清ノ & 13.0 & 加抗血清 7 & 體結合反 \\
\hline & 0.15 & 0.001 & 8.0 & 1.0 & $\Xi 卜 ノ \mathrm{SRR}$ & 15.0 & モッテノ & 㗹ノ晹性 \\
\hline & 0.15 & 0.003 & 8.0 & 2.0 & 八和） & 20.0 & RR & 程度 \\
\hline 對 & \multicolumn{5}{|c|}{ 溶血系加補體 $\left.\left(I_{0} 0.03\right)=テ\right)$} & 29.0 & & \\
\hline
\end{tabular}

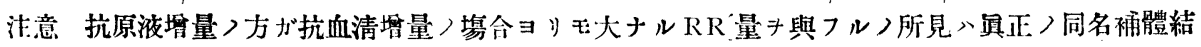

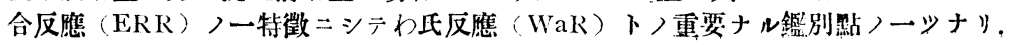
倍數法則立證セラレタリ $(6.5 \times 3 \fallingdotseq 20.0)$ 
第 17 表 腸ちふす菌煮沸先疫元透析内液乃至抗血清ノ單獨 補體結合反應並二兩者 $\ni$ 以テセル第 3 型乙補體結合 反應（にんひぞりん反應陽性）

\begin{tabular}{|c|c|c|c|c|c|c|c|c|}
\hline \multirow{2}{*}{ 抗原種別 } & \multirow{2}{*}{$\begin{array}{c}\text { T } \\
\text { 抗原量 } \\
(\mathrm{cc})\end{array}$} & \multirow{2}{*}{$\begin{array}{l}\text { 而抗血清量 } \\
\text { (cc) }\end{array}$} & \multicolumn{3}{|c|}{ 單獨補體結合二ヨル殘留血球量 } & \multicolumn{2}{|c|}{$\begin{array}{l}\text { 抗原加抗血清補體結 } \\
\text { 合ニヨル殘留血陫量 }\end{array}$} & \multirow{2}{*}{$\frac{\text { 埴强度 }}{\text { IV-吕 }}$} \\
\hline & & & $\mathrm{S} \mathrm{R} R$ & $\mathrm{SI}_{\mathrm{R}} \mathrm{R}$ & $\begin{array}{c}\mathrm{S} \quad \mathrm{R} \\
(I \mathrm{II}) \\
\mathrm{I}\end{array}$ & $\begin{array}{l}I+\mathbb{I} \\
\text { ERR }\end{array}$ & $\begin{array}{l}\text { E R R J } \\
\text { 總 和 IV }\end{array}$ & \\
\hline \multirow{4}{*}{$\begin{array}{l}\text { 腸ちふす菌港 } \\
\text { 沸免疫元（透 } \\
\text { 析內液） }\end{array}$} & 0.05 & 0.001 & 3.0 & 1.0 & 26.0 (抗原) & 6.0 & 52.0 （抗原 & 26.0 （補 \\
\hline & 0.05 & 0.003 & 3.0 & 20 & ミ卜抗血清 ノ & 13.0 & 加抗血淸 & 體結合反 \\
\hline & 0.15 & 0.001 & 7.0 & 1.0 & $ミ R, S R R$ & 14.0 & モッテノ & 礁ノ陽性 \\
\hline & 0.15 & 0.003 & 7.0 & 2.0 & 八和） & 19.0 & RR) & 程度） \\
\hline 對 & \multicolumn{5}{|c|}{$\begin{array}{l}\left.\text { 溶血系加補體 }\left(L_{0} 0.03\right)=テ\right) \\
\text { 全 血 球 量 }\end{array}$} & $\begin{array}{c}\text { 痕 } \\
29.0\end{array}$ & & \\
\hline
\end{tabular}

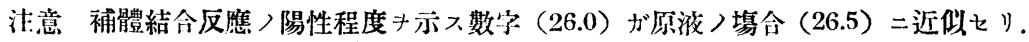

倍數法則立證セ フレタリ $(6 \times 3 \fallingdotseq 19.0)$

第 18 表 腸ちふす菌煮沸先疫元透析外液乃至抗血清，單獨 補體結合反應並二雨者 $\ni$ 以ティル第 3 型乙補體結合 反應（にんひに゙りん反應陌性）

\begin{tabular}{|c|c|c|c|c|c|c|c|c|}
\hline \multirow{2}{*}{ 抗原種別 } & \multirow{2}{*}{$\begin{array}{c}\text { I } \\
\text { 抗原量 } \\
(\mathrm{cc})\end{array}$} & \multirow{2}{*}{$\begin{array}{c}\text { Iㅡ } \\
\text { 抗血清量 } \\
\text { (c) }\end{array}$} & \multicolumn{3}{|c|}{ 單獨補體結令二ヨル殘留血球量 } & \multicolumn{2}{|c|}{$\begin{array}{l}\text { 抗原加抗血清補體絬 } \\
\text { 今心ョョル琖留血球量 }\end{array}$} & \multirow{2}{*}{$\frac{\text { 增强度 }}{I V-\text { III }}$} \\
\hline & & & $\mathrm{S} \stackrel{\mathrm{I}}{\mathrm{K}} \mathrm{R}$ & $\mathrm{S} \underset{\mathrm{R}}{\mathrm{II}} \mathrm{R}$ & $\begin{array}{c}\mathrm{S} \\
(I \mathrm{II}) \text { ) }\end{array}$ & $\frac{I+\mathbb{I}}{(\mathrm{ERR})}$ & $\begin{array}{l}\mathrm{E} R \mathrm{R} / \\
\text { 總 和 } \mathbb{N}\end{array}$ & \\
\hline \multirow{4}{*}{$\begin{array}{l}\text { 腸5 子寸囷意 } \\
\text { 沸免疫元（透 } \\
\text { 析外液） }\end{array}$} & 0.05 & 0.001 & 2.0 & 1.0 & 16.0 (抗原) & 2.0 & 13.0 （抗原 & -3.0 (補 \\
\hline & 0.05 & 0.003 & 2.0 & 2.0 & ミ卜抗血清 & 3.0 & 加抗血清 & 體結合反 \\
\hline & 0.15 & 0.001 & 3.0 & 1.0 & ミ卜, ERR & 4.0 & モッテノ & 應〉陽性 \\
\hline & 0.15 & 0.003 & 3.0 & 2.0 & 八和） & 4.0 & $\mathrm{RR}$ ) & 程度） \\
\hline 對 & \multicolumn{5}{|c|}{$\begin{array}{l}\left.\text { 溶血系加補 }\left(\mathrm{L}_{0} 0.03\right)=テ\right) \\
\text { 全 血 球 毁 }\end{array}$} & $\begin{array}{c}\text { 痕 } \\
29.0\end{array}$ & & \\
\hline
\end{tabular}

注意 抗原ノミ卜抗血清ノミノSRK ノ總和. (16.0) 力゙抗原加抗血清 ERR （13.0）ヨリ火

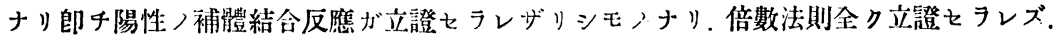

\section{所見及 ビ 考察}

（1）者沸免疫元原液透析內液及ビ抗血清ノ何レヨ增量セシムルモ本實驗 範 圍內二於テハ夫々殘留血球量ノ增加 來タセルモ特二抗原量 $习$ 增加ヤシムル方 


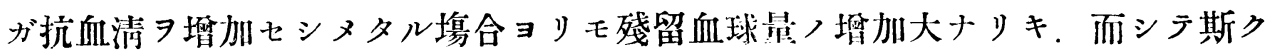

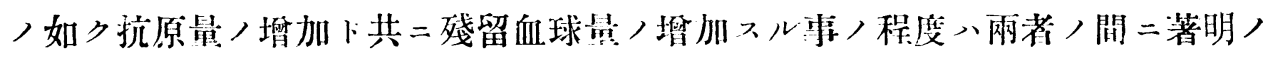
差異ヨ認メザリキ，換言フレバ殆ンド同等ノ補體結合ヨ管ミタルモノナリ.

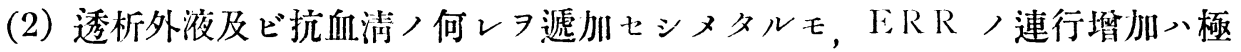
タテ微々タルモノニ過ギザリキ.

（3）郎チ抗原量 $0.05 \mathrm{cr}$ 抗血清 $0.003 \mathrm{cc} ト ニ ヨ ル$ 補體結合反應ノ殘留血球量: 八者沸先疫元原葆 13.0透析内液 13.0透析外液 3.0 ナル二抗原量 $0.15 \mathrm{cc}$ 卜抗血清 量 $0.001 \mathrm{cc} ト ニ ヨ ル$ 補體結合反應, 殘留血球量八素沸先疫元原液 15.0 透析内 液 14.0 透析外液 4.0 ヨ示シタリ。

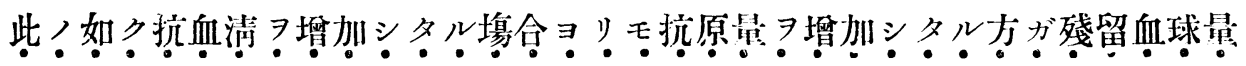

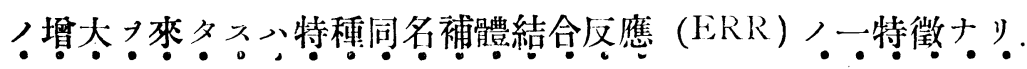

（4）抗原量 $0.05 \mathrm{cc}$ 卜抗血清 $0.001 \mathrm{cc} ト ニ ヨ ル$ 補體結合反應二於ケル殘留血 球昆入者沸凭疫元原液 6.5 透析内液 6.0 ナル二抗原抗血清量共 $=3$ 倍ナル抗原 $0.15 \mathrm{cc}$ 卜抗血清 $0.003 \mathrm{cc} ト ニ ヨ ル$ 補體結合反應, 殘留血球量入煮沸先疫元原液 20.0 透析內液 19.0 ニシテ略々前記殘留血球量ノ 3 倍ニ相當シタリ. 是郎チ倍數

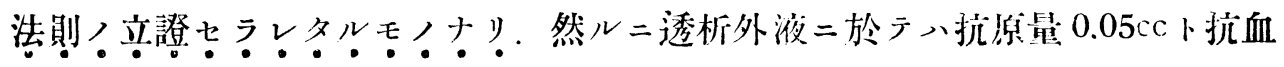
声 $0.001 \mathrm{cc} \mapsto=\Xi ル$ 補體結合反應二於ケル殘留血球ハ 2.0 ナルニ抗原及ビ抗血 清量共二 3 倍ナル抗原 $0.15 \mathrm{cc}$ ト抗血清 $0.003 \mathrm{cc}$ トニョル補體結合反應ノ殘留血 球量、 4.0 二シテ抗原 $0.15 \mathrm{cc}$ 抗血清 $0.001 \mathrm{cc} ト$ ト 球量 4.0 二全ク等シクシテ前記殘留血球量，倍ニ相等シタリ．郎き倍數律！立 澄ハ成立セザリキ。

（5）本實驗二於テ者沸隹疫元原液及ビ透析内液、何レモ抗血清 際ヨリモ，拜原量 $コ$ 增加シタル韵合二殘留血球量ノ大トナリタル前記（3）， 所見及ビ抗體抗原ノ結合二際シテ略々倍數法則ガ成立スルモノナルコト，郎チ 定梨的ノ結合ヨ營ムモノナルコトガ併セテ立證セラレタリ。而シテ此所見、本 實驗二於テ立證シ得タル陽性結合反應がわ氏反應ニモアラズ．ふ氏抗體抗原， 反應ニモ非ズシテ，正二同名特種性ノ補體結合反應ナルコトノ一特徵タルモノ

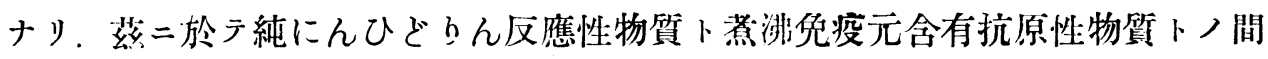
二於ヶル相互關係ハ既二立證セラレタル先疫獲得，實際結果二於テノ所見卜相 
俟チテ率々確實二證明セラレタルモノト信ズ。

\section{第 7 章 所見總括及ビ考察}

余等八腸ちふす菌惹沸免疫元原液，同透析内液及ビ透析外液八補體結合反應

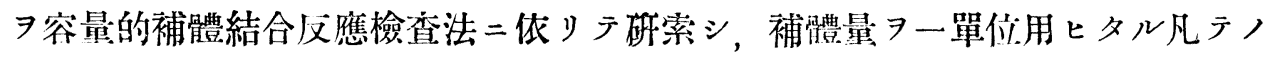

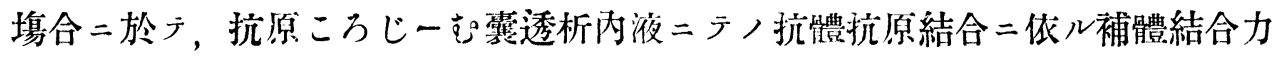

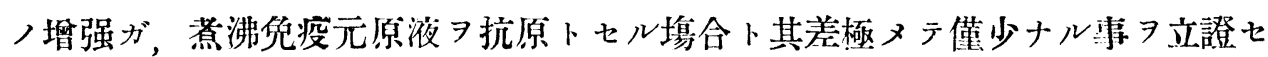
リ換言スレバ兩者ノ補體結合性ハ何等格段ノ差ヨ認き得ザリキ之レ二反シテ透 析外液=にんひぞりん反應性物貿ニアリティ,

抗原 SRR＋抗血清 SRR<(抗原+抗血清) E.RR ナル關係八立證セラレザ リシモノナリ。換言スレバ具ノ補體結合反應 (ERR) 八泿跡ダニモ證明セラレ 得ザリシモノナリ。以上ノ所見ハ惹沸帒疫元ノ所謂抗原性物質ナルモノハこク ビーさ囊ヨ全然透析シ得ザルモノニシテ，透析物質二純にんひどりん反應性物 質ノミヨ以テハ最早抗原性能働力 $习$ 發揮シ得ザルモノト思考セザルへカラズ.

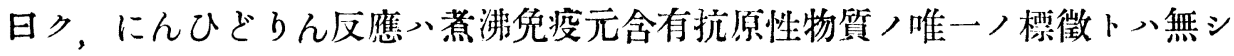
得ザルモノナリ且又、余等ノにんひどりん反應性物質卜㑆疫獲得，實際結果二 於ヶル立證トモ亦饪ク一致スルモノナル事ヨ知ル心゙，以テ立證的意義ノ重大

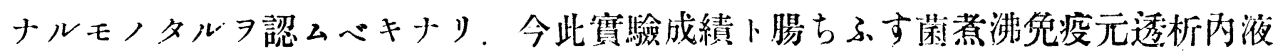
及ビ透析外液ヨ注射七ラレタル家鬼血清同株菌二依ル凝集反應检查成績トヨ綜 合スル時二、晹ちふす菌煮沸㧤疫元透析內液及ビ透析外液二テ試驗管內二於テ 抗原性能動力大 (小) ナル或、無キ抗原八動物體中二於テモ, 亦先疫元性能動 力大 (小)ナルモノ或、無キモノナリ。トノ克疫學上ノ一般原則ガ立證セラレタ ル次第ナリ。蓋シ抗原ナルモノハ一面試驗管內ニテ眞性ノ抗體抗原ノ各種結合 习營䉆シ，又他面動物蹬中二於テハ，直テ二免疫元トシテ，作用シ得ル物質 示指スルモノニシテ免疫元タルノ作用ナクシテ單二草驗管中二於テ抗體卜或一 秏，結合 營么如キ八是，真倜ノ抗原二非ズシテ假性抗原卜謂フ可キモノナ

リ。カクノ如キ鑑別點ヨリ考察スレバ菌純培食惹沸ニョリテ產出セラル、にん ひぞりん反應性物質及ビ類脂體八正二假性抗原二屬スルモノニシテ抗體抗原間 ノ定梨的ノ結合ヨ示サベルモノト云ハザルぶカズ，郎チ腸ちふす菌著沸先疫 
元э類脂體にんひどりん反應性物塤及ビ菌蛋白質，三要素二分析哈味考察セル 塲合二，類脂體にんひぞりん反應性物質個々ノミア以テン，抗原性能働力，換

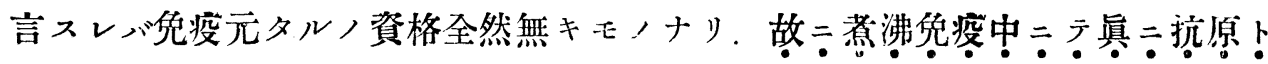

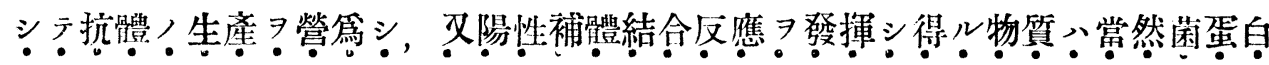

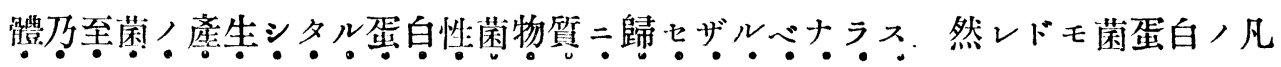
テガ抗原性物質, 標徵ナリヤ, 更二進ミテ秃原トナリ得ル菌蛋白體卜入, 果シ テ如何ナルモノヨ以テ指示シ得ルャ,制定二向ッテハ今後, 研究 ナリ。

\section{第 8 章 結論}

（1）容量的補體結合反應檢查方法、從來知ラレタル，補體結合，如何ナル檢 查方法ヨリモ，更ニ一層精密ナルモノニシテ且ッ真二學術的，(數量的)ナリ. 此ノ檢查方法二據ラザル一切, 補體結合反應ノ結果八學術上殆ンド意義 ザルモノナリ。

（2）腸ちふす菌煮沸免瘦元原液同透析内液及ビ透析外液二純にんひぼりん反 應性物質 $夫$ ぬ抗原トナシ, 容量的補體結合ニョリ其抗原性能働力 7 研究シ,

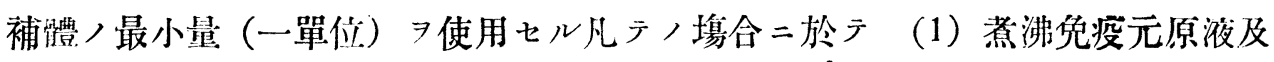

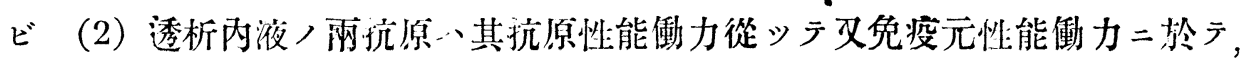
殆ンド優劣 認メ得ザリキ，之レ二反シ（3）透析外液＝純にんび゙りん反應 性物凝二菌蛋白分解產物ニアリテ リキ。

（3）補體結合反應ガ真二陽性ナリヤ，陰性ナリヤ，判定二向ッテハ抗原ノミ 八補蹧結合力ト抗血清ノミノソレト抗原加抗血清习以テノソレトノ比較》求ム ル事ヨ要ス。此方法ニョリテ，補體結合反應览性，陰性ノ別 7 正シク制定シ， 且其陽性，陰性ノ程度 數字上二明示シ得ルヒノナリ。從來, 補體結合反應檢 查方法ニテハ，カクノ如キ制斷、到底出來ザルモノナリ。

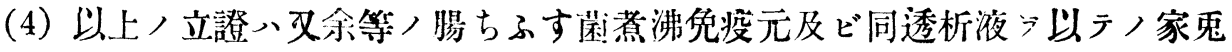
ニ於ケル實際免疫，結果トモ全ク一致スルモノニシテ抗原性能働力無キモ， 八，又等シク免疫元性能働力 $习$ 保有セズ，抗原卜免疫元卜八異名同一物 (ident 
isch)ナリ。卜先疫學上ノ一般的法則 ヨ立證シ得タルモヒナリ。

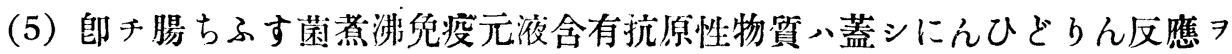
以テ標徵トハナシ得ザルモノナリト知ルバシ，換言スレバにんひぞりん反應性 物質二菌蛋白分解產物ナルモ八腸ちふす菌嶚沸免疫元ノ主體习指示スルモ， ニアラザル、勿論，コレト何等關係無キモノナリ．但シにんひぞりん反應，著 明ナル惹沸免疫元二於方、其，然ラザルモノョリモ本來，免疫物質，含量モ亦 タ大ナルベシトノ推定 下スコトハ許容セラルぶシ.

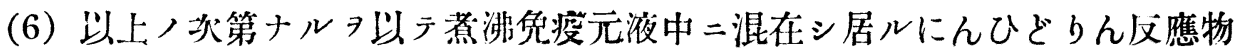
質八免疫上無害無効ナリヤ，或入無勃有害ナリヤト言フ新タナル疑問 $コ$ 生ズル ニ至リタリ。此ノ解决八蓋シ賽用上必要ナルー事項ナルベシ。

\section{文献}

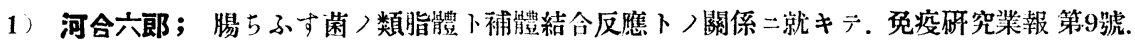

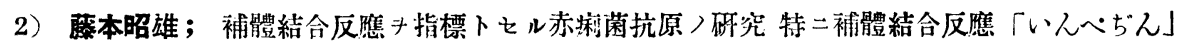
象現，東京醫學會雜誌 第39卷 第9號.

3）上田温恶；容量的補體結合反礁檢查方 法及ビ容量的補體結合反倠微量檢查力法苕ビ二補體結合反應基䃈的所見. 東京醫學會雜誌第38卷 第 5 號.

4）中野生清； 特殊性及ビ非特種性:補體結合反㤰入鑑別。東京醫學會雜誌 第40卷 第7號.

5）佐野正規；「抗體」「抗原」八依的兒處理卜補體結合反䍚，同名 補體結合反礁 (ERR) 本態論. 東京醫學會雜誌 第40卷 第5 5 否。

6) 山本宗三郎;

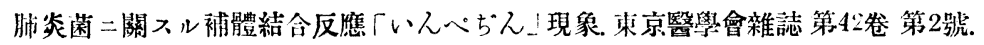

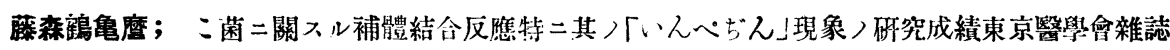
第 41 卷 第11號.

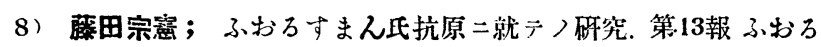
すまん氏抗原つ本態及ビ鑑別點(ERR補體結合反㟲)東京醫學會雜誌 第41卷 第6號.

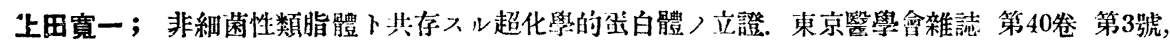
10) R. Torikata; Die volumetrische Komplementhindungsreaktion Jene Verlag von Gustav Fischer 1928.

11）猪木隆三；港沸免疫元卜シテハ上澄波卜溜過波卜们レ

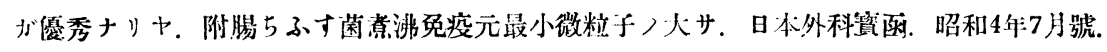

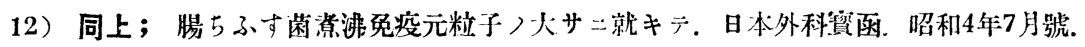

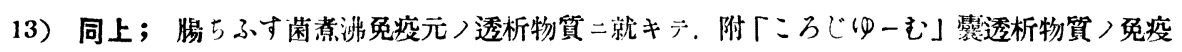
學上>意義. 日本微生物. 病理學雜誌. 昭和.1年8月號.

14）藤網晨一; 哴灀現象卜

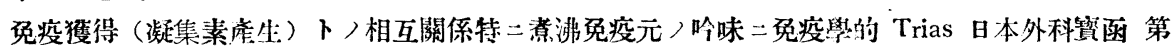
5 卷 第- - 號.

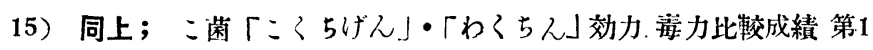
報 免疫研究策報 第21號. 16）同上；免湥元トシテノ菌體 >價値 第1及ビ第2報 日本外科䆩函第 5 卷 第 1 號 17）勝吕惈；傳研製腸5小寸囷「わ了5ん」卜同名 菌「こくらげん」卜ノ効力. 竘力八比較 日本外科空函第5卷 第 6 號. 


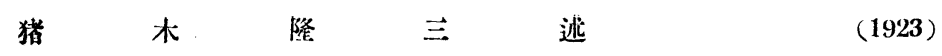

\title{
Ergeben die Ninhydrin-positive Substanzen im Typhusbazillenk ok toimmunogen die spezif ische Komplementbindungsreaktion?
}

\author{
von \\ Dr. R. Inoki
}

〔Aus dem Laboratorium der Kais. chirur. Universitätsklinik Kyoto (Prof. Dr.

R. Torikata)]

Von einer 48-stündigen Agarkultur von Typhusbazillen stellten wir eine Kochsalzaufschwemmung der Erreger im Verhältnisse von ca. $0.0035 \mathrm{ccm}$ Baktrerienleiber auf $1.0 \mathrm{ccm}$ Medium her, rersetzten dieselbc mit 0.5 pro\%. Karbolsäure, hielten einc halbe Stunde in einem bei $100^{\circ} \mathrm{C}$ siedenden Wasserbade und dann abzentrifugiert. Das Zentrifugat wurde durch eine $\mathrm{L}_{3}$-Thonkerze getrieben und so stellen wir eine Typhusbazillenkoktoimmunogen her.

Das auf diese Weise erhaltene Koktoimmnuogen ergab eine mittelmässigr stark positive Ninhydrinreaktion.

Das Koktoimmunogen teilten wir in zwei gleiche Portionen. von dehnen die eine zur Kontrolle und die andere, 24 Stunden lang durch eine 5 Minuten getrocknete Kollodiummembran dialysiert zur nachstehenden Prüfung herangezogen wurde.

Zur Kontrollierung des Grades der Ninhydrinreaktion bedienten wir uns des E. Adnet' schen Constricteurs und erhielten die folgenden Verhältnisse : Original-Elüssigkeit: Innen-Flüssigkeit: Aussen-Flüssigkeit=100.0: 52.3: 47.7

Als ein gleichnamiges Antiserum haben wir das Serum eines Kaninchens herangezogen, welches eine bei $100^{\circ} \mathrm{C} 30$ Minuten lang crhitzte Kochsal\%aufschwemmung von Typhusbazillen $(0.0035 \mathrm{ccm}$ im $1.0 \mathrm{ccm})$ innerhalb 5 Tage in der Menge von $1.5 \mathrm{ccm}$ intravenös erhalten hatte.

Die Blutentnahme erfolgte am 7. Tage nach der letzten immunisierenden Injektion. Das Serum wurde durch eine halbstündige Erhitzung bei $56 \mathrm{C}$ inalitiviert, mit 0.3 proz. Karbolsäure versetzt. Der Agglutinintiter des Serums betı ug dabei 1: 8000. Die Ergebnisse der Versuche mittels der volumetris- 
chen Komplementbindungsmetlıode, ob eine antigene Wirkung den Ninhydrin-positiven Substanzen zukomme, gehen aus den folgenden Tabellen I und II hervor.

Tabelle I

\begin{tabular}{|c|c|c|c|c|}
\hline \multirow{2}{*}{ No. } & \multirow{2}{*}{ Art des Antigens } & \multicolumn{3}{|c|}{ RR Menge von } \\
\hline & & Orig.-Flüss. & Innen-Flüss. & Aussen-Flüss. \\
\hline 1 & $\begin{array}{l}\text { Summe von } S R R \\
\text { bei Antigen allein }\end{array}$ & 54.0 & 51.0 & 18.0 \\
\hline 2 & $\begin{array}{l}\text { S R R bei Antiserum allein } \\
0.001 \mathrm{ccm} \times 6\end{array}$ & 6.0 & 6.0 & 6.0 \\
\hline 3 & $\begin{array}{l}\text { S R R bei Antiserum allein } \\
0.002 \mathrm{ccm} \times 6\end{array}$ & 6.0 & 6.0 & 6.0 \\
\hline 4 & $\begin{array}{l}\text { M R R } \\
\text { (Summe von } 1 \text { u. 2) }\end{array}$ & 60.0 & 57.0 & 24.0 \\
\hline 5 & $\begin{array}{l}\text { M R R } \\
\text { (Summic von } 1 \text { u. } 3 \text { ) }\end{array}$ & 60.0 & 57.0 & 24.0 \\
\hline 6 & $\begin{array}{l}\text { Summe von } E R R \\
\text { (bei Antigen }+ \text { Antiserum } \\
0.001 \mathrm{ccm} \text { ) }\end{array}$ & 94.0 & 89.0 & 14.0 \\
\hline 7 & $\begin{array}{l}\text { Summe von } E R R \\
\text { (bei Antigen }+ \text { Antiserum } \\
0.002 \mathrm{ccm} \text { ) }\end{array}$ & 111.0 & 105.5 & 17.0 \\
\hline 8 & $\begin{array}{l}\text { Zunahme von } \mathrm{RR} \text { Menge } \\
(6-4)\end{array}$ & $34.0 *$ & $32.0 *$ & $-10.0 * *$ \\
\hline 9 & $\begin{array}{l}\text { Zunahme von } \mathrm{RR} \text { Menge } \\
(7-5)\end{array}$ & $51.0 *$ & $48.5 *$ & $-7.0 * *$ \\
\hline
\end{tabular}


獜隆三逃

(1925)

Tabelle II

\begin{tabular}{|c|c|c|c|c|}
\hline \multirow{2}{*}{ No. } & \multirow{2}{*}{ Art des Antigens } & \multicolumn{3}{|c|}{$\mathrm{R} R$ Menge von } \\
\hline & & Orig.-Flüss. & Innen-Flïss. & Aussen-Flüss. \\
\hline 1 & $\begin{array}{l}\text { Summe von } \mathrm{S} R \mathrm{R} \\
\text { bei Antiserum allein }\end{array}$ & 9.0 & 9.0 & 9.0 \\
\hline 2 & $\begin{array}{l}\text { S R R bei Antigen } 0.05 \\
\text { allein } \times 6\end{array}$ & 18.0 & 18.0 & 12.0 \\
\hline 3 & $\begin{array}{l}\text { M R R } \\
\text { (Summe von } 1 \text { u. 2) }\end{array}$ & 27.0 & 27.0 & 21.0 \\
\hline 4 & $\begin{array}{l}\text { Summe von E R R (bei } \\
\text { Antigen + Antiserum) }\end{array}$ & 67.0 & 64.0 & 14.0 \\
\hline 5 & $\begin{array}{l}\text { Zunahme ron } R \mathrm{R} \text { Menge } \\
(4-3)\end{array}$ & $40.0 *^{\bullet}$ & $37.0 *$ & $-7.0 * *$ \\
\hline
\end{tabular}

* Die Zahlen geben den Grad der Positivität der spelifischen Komplementbindungsreaktion an.

** Hier wird die Negativität der Reaktion zahlenmässig angegeben.

\section{Zusammenfassung.}

1) Das Dialysat des Typhusbazillenkoktoimmunogens, welches einerseits eine (100: 47.7) positive Ninhydrinreaktion, andererseits keine Agglutinin erzeŭgende Fähigkeit aufwies, ergab ausnamslos eine deutlich negative (10,0 bzw. -7.0) Komplementbindungsreaktion.

2) Die Innen-Flüssigkeit nach der Dyalyse, die einerseits eine gegenüber dem Original ungefähr zur Hälfte $(100: 52.3)$ verminderte Ninhydrinreaktion ergab, andererseits fast den gleichen Agglutinintitel erzeugte, lies die Spezifische Komplementbindungsreaktion in dem Masse konstatieren, wie das originale Koktoimmunogen ohne Dialyse, indem sich die Positivität der 
Reaktion als 48.5 bzw. 37.0 beim ersteren und 51.0 bzw. 40.0 beim letzteren herausstellte.

3) Daraus geht folgendes heror:

1. Ninhydrinpositive Substanzen sind weder Antigene noch Immunogene.

2. Die immunisatorischen Eigenschaften in vivo und die antigene ( $z$. b. komplementbindenden) Wirkungen in vitro sind quantitativ als identisch zu betrachten (Autoreferat). 